Pacific Northwest National Laboratory

Operated by Battelle for the U.S. Department of Energy

\section{Establishment of a Cost-Effective and Robust Planning Basis for the Processing of M-91 Waste at the Hanford Site}

\author{
W. L. Johnson \\ B. M. Parker
}

July 2004

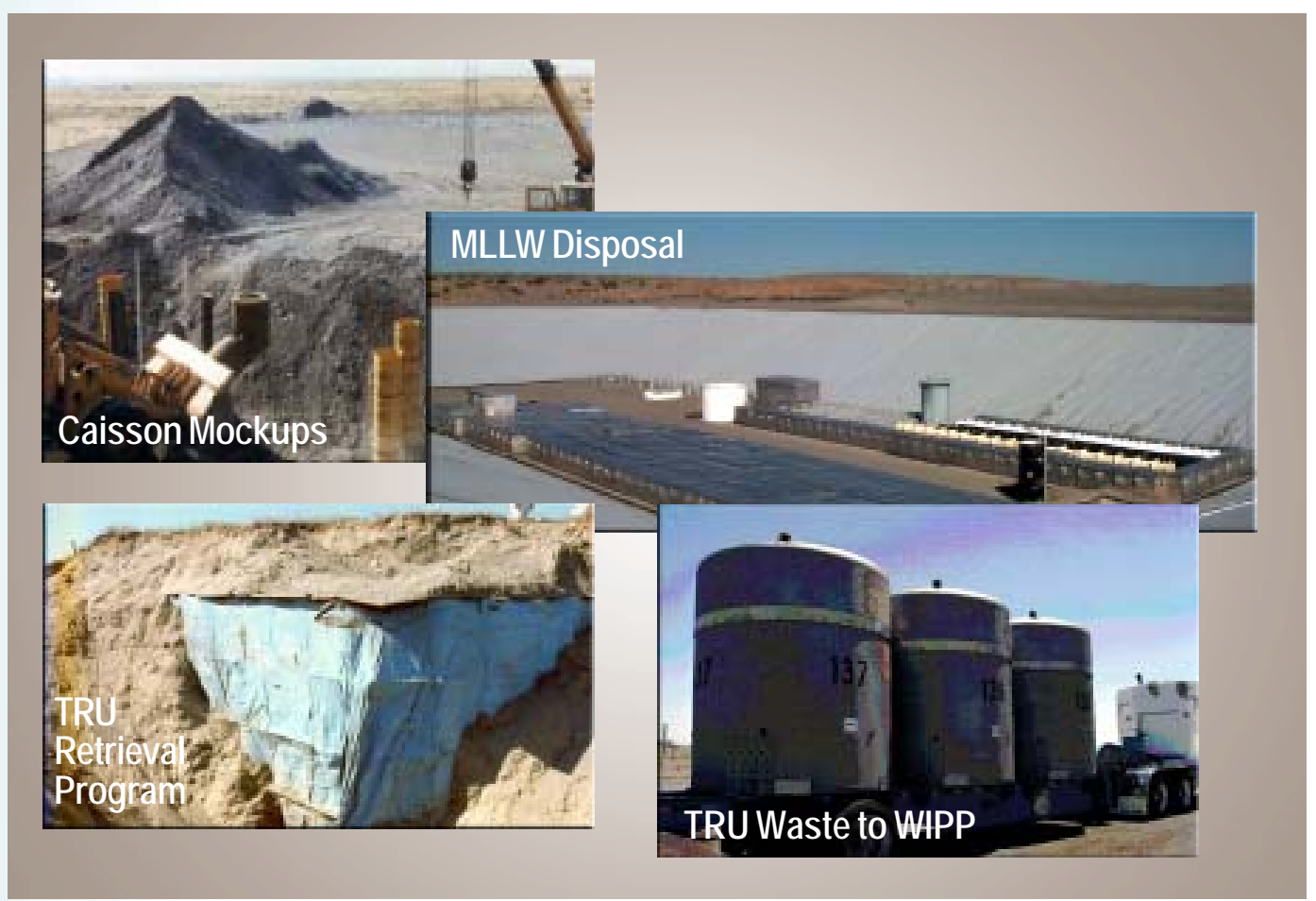

Prepared for Fluor Hanford, Inc.

Sponsored by the U.S. D epartment of Energy under Contract DE-AC06-76RL01830 


\title{
DISCLAIMER
}

This report was prepared as an account of work sponsored by an agency of the United States Government. Neither the United States Government nor any agency thereof, nor Battelle Memorial Institute, nor any of their employees, makes any warranty, express or implied, or assumes any legal liability or responsibility for the accuracy, completeness, or usefulness of any information, apparatus, product, or process disclosed, or represents that its use would not infringe privately owned rights. Reference herein to any specific commercial product, process, or service by trade name, trademark, manufacturer, or otherwise does not necessarily constitute or imply its endorsement, recommendation, or favoring by the United States Government or any agency thereof, or Battelle Memorial Institute. The views and opinions of authors expressed herein do not necessarily state or reflect those of the United States Government or any agency thereof.

\author{
PACIFIC NORTHWEST NATIONAL LABORATORY \\ operated by \\ BATTELLE \\ for the \\ UNITED STATES DEPARTMENT OF ENERGY \\ under Contract DE-AC05-76RL01830
}

Printed in the United States of America
Available to DOE and DOE contractors from the Office of Scientific and Technical Information,
P.O. Box 62, Oak Ridge, TN 37831-0062;
ph: (865) 576-8401
fax: $(865)$ 576-5728
email: reports@adonis.osti.gov

\begin{abstract}
Available to the public from the National Technical Information Service, U.S. Department of Commerce, 5285 Port Royal Rd., Springfield, VA 22161 ph: (800) 553-6847 fax: $(703) 605-6900$ email: orders@ntis.fedworld.gov online ordering: http://www.ntis.gov/ordering.htm
\end{abstract}

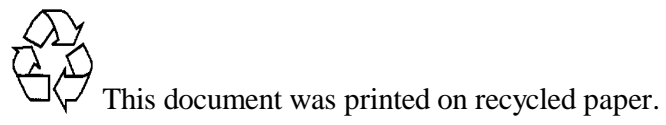




\title{
Establishment of a Cost-Effective and Robust Planning Basis for the Processing of M-91 Waste at the Hanford Site
}

\author{
W. L. Johnson \\ B. M. Parker
}

July 2004

Prepared for Fluor Hanford, Inc.

Sponspored by the U.S. D epartment of Energy under Contract DE-AC06-76RL01830

Pacific Northwest National Laboratory

Richland, Washington 



\section{Summary}

The objective of this evaluation is to identify and evaluate viable alternatives for the accelerated processing of Hanford Site transuranic (TRU) and mixed low-level wastes (MLLW) that cannot be processed using existing site capabilities. Accelerated processing of these waste streams will lead to earlier reduction of risk and considerable life-cycle cost savings. The processing need is to handle both oversized MLLW and TRU containers as well as containers with surface contact dose rates greater than $200 \mathrm{mrem} / \mathrm{hr}$ (referred to as remote-handled [RH] waste). This capability is known as the "M-91" processing capability required by Tri-Party Agreement (TPA) milestone M-91-01. Figure S.1 provides a conceptual view of the binning of M-91 wastes into functional categories that can then be processed in an accelerated manner.

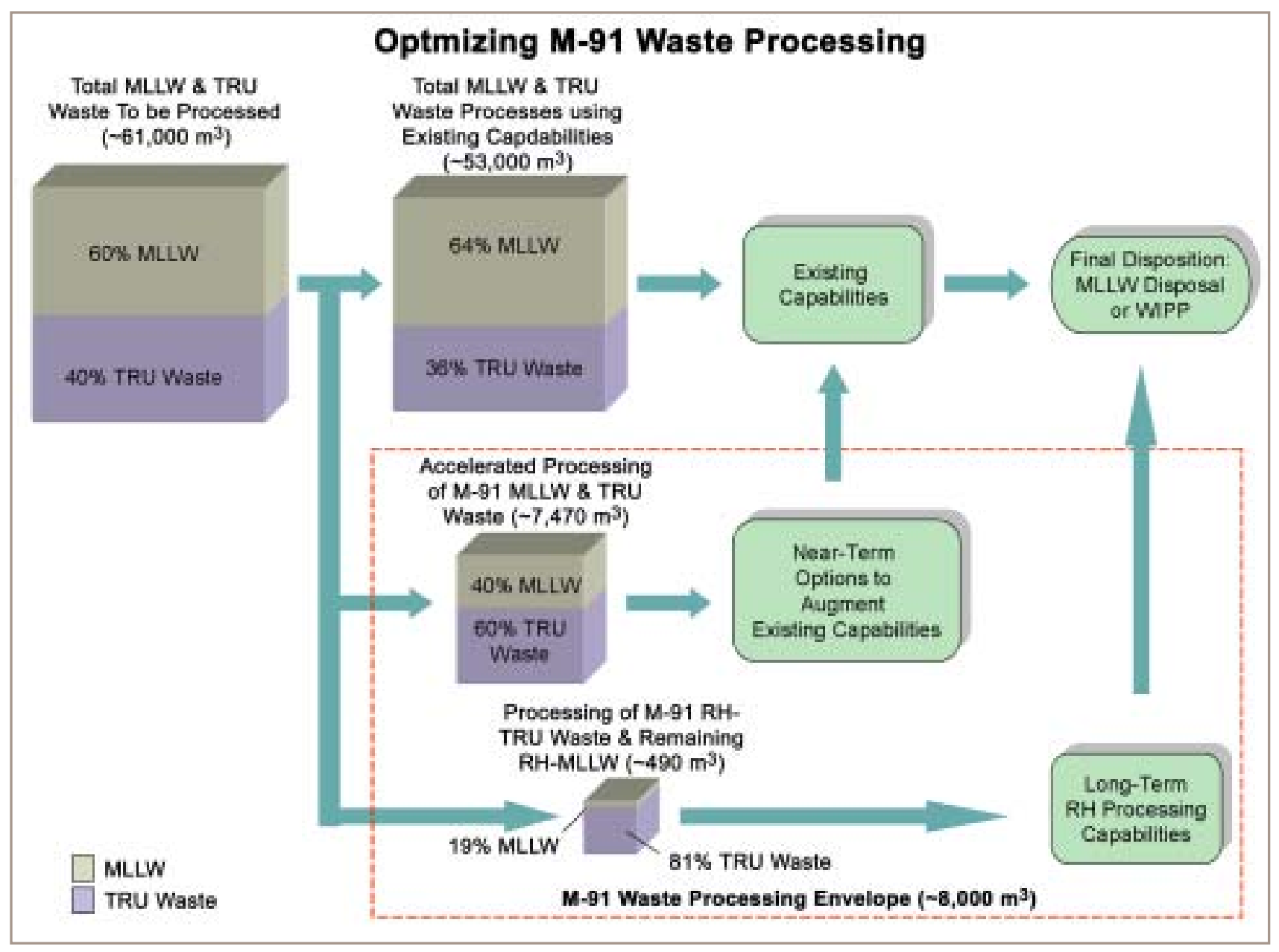

Figure S.1. M-91 Waste Conceptual Processing Flow Diagram

In developing a preferred M-91 processing approach and associated path forward, the following guiding programmatic goals and principles were employed:

- Select options that accelerate processing of waste in storage (early reduction of, or avoidance of, waste backlog).

- Maximize the use of existing onsite capabilities, commercial capabilities, or limited capability upgrades to reduce the capital cost and schedule impacts associated with new processing facilities or modules. 
- Continue to gain experience and practical knowledge in the repackaging and processing of contact-handled $(\mathrm{CH})$ waste prior to embarking on the processing of the more difficult and hazardous $\mathrm{RH}$ waste streams.

- Ensure all capabilities needed are in place for the processing of the M-91 waste (no identified gaps) and that there is flexibility (backup capability and potential for expansion) where possible.

- Optimize the use of recommended facilities/ capabilities to avoid operational impacts (e.g., cycling of resource needs due to high variations in processing rates and requirements) and the associated cost inefficiencies.

- Select options that accelerate completion of the overall processing program and enable the earliest possible shutdown of individual facilities/ capabilities.

Based on the results of this evaluation, a number of recommendations are made in an effort to accelerate processing, maintain a degree of flexibility and redundancy in processing capabilities (to respond to potential future changes in the waste generation, processing requirements, or expected volumes), and enable early start and completion of the processing mission. Table S.1 summarizes the current M-91 waste stream projections along with the recommended path forward for processing these wastes.

Table S.1. M-91 Waste Stream Forecasts and Preferred Alternative Processing Approach and Assumptions

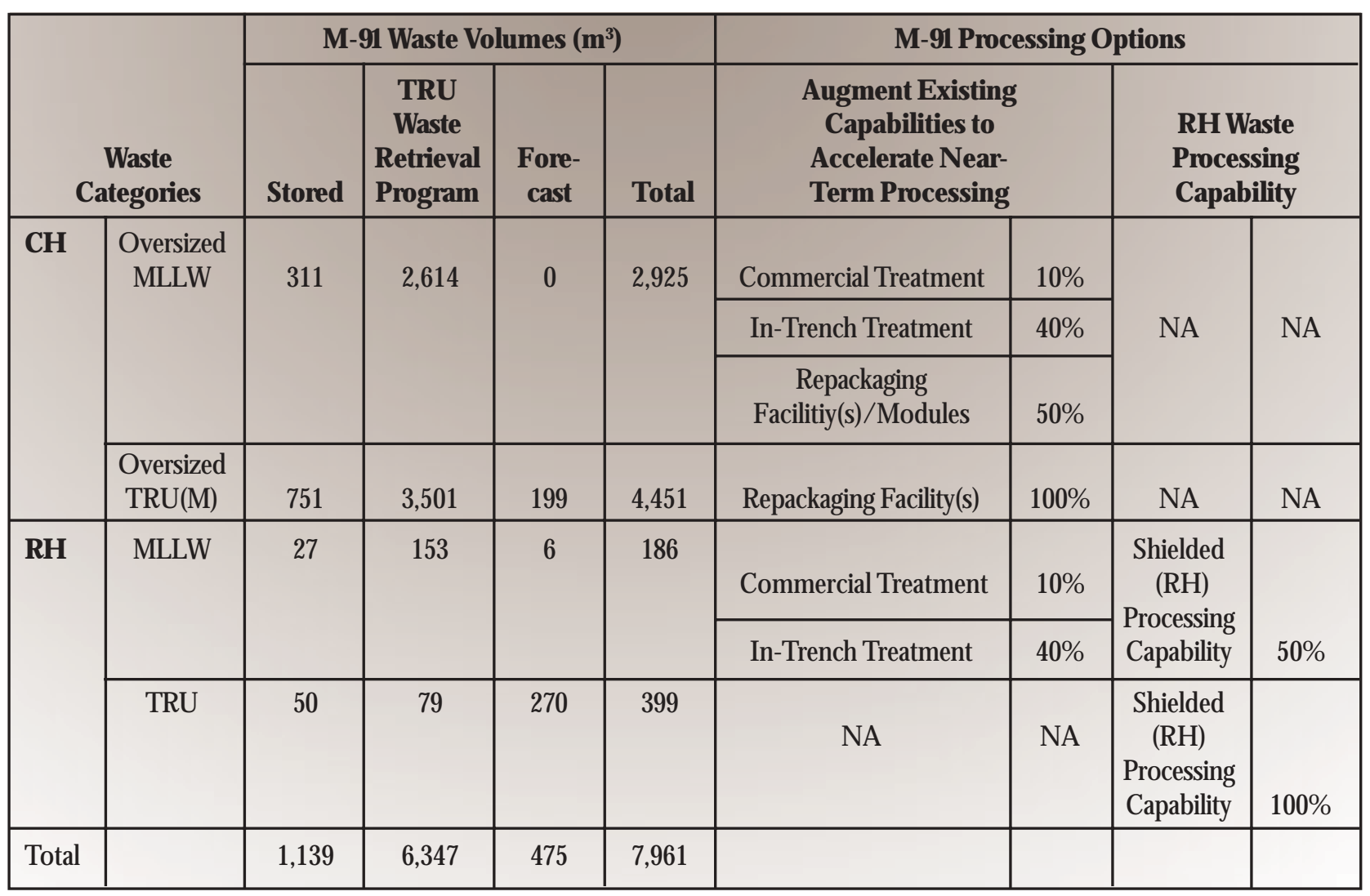

The new, phased approach proposed in this evaluation would use a combination of existing and planned processing capabilities to treat the more easily managed $\mathrm{CH}$ waste streams first and would provide for earlier processing of these wastes. This proposed approach would not only accelerate initiation of the processing of the M-91 waste streams, but would significantly complete the processing mission ahead 
of the previous baseline and the TPA-mandated processing rates and schedules by nearly a decade. As a result of the early retirement of the T Plant facility due to accelerated processing of M-91 waste (including the expanded use of offsite and in-trench treatment), an estimated life-cycle savings of nearly $\$ 125$ million is predicted. The following specific actions are recommended to achieve this level of potential savings:

- Continue efforts to reduce the volume of waste that needs processing by an M-91 capability, including supporting Treatment-by-Generator processing and encouraging retrieval operations to package waste in standard-size containers if possible. Work with tank farm operations and closure contractor(s) to determine if alternative capabilities can be provided for the waste generated after 2019.

- Expand existing commercial MLLW treatment contracts to accept larger and higher-dose-rate packages.

- Work with the regulators to allow in-trench treatment for a portion of the oversized and RH MLLW.

- Conduct an engineering study in FY05 to define the size reduction and repackaging capabilities needed to accelerate the processing of the oversized CH-MLLW and CH-TRU waste in storage and expected to be generated by the TRU Retrieval Program. O ptions including modification of existing facilities, use of modules within or adjacent to existing facilities, and use of temporary containment enclosures should be considered. Acquire this capability in FY 06 to allow processing to commence in FY07, allowing all stored, generated, or retrieved CH M-91 wastes to be processed by 2012.

- Beginning in FY06, initiate the solicitation process, through a request for interest, to ascertain the viability of implementing a commercial processing capability for the RH-TRU and remaining RH-MLLW.

- Conduct an engineering study in FY 06/ 07 (in conjunction with the release of the WIPP RH-TRU WAC) to define the RH waste processing and treatment capabilities needed to complete the M-91 processing mission.

- Based on the solicitation process and the engineering study, a decision point will occur in late 2007 (in conjunction with TPA Milestone M-91-05-T01) to determine the preferred $\mathrm{RH}$ processing approach. This capability will then be acquired (FY 08-FY11), allowing limited processing to commence in FY12 and potentially earlier.

- Optimize T Plant facility upgrades and operational missions to continue to reduce the volume of back-logged waste, and provide continuity of waste processing missions and expertise.

The M-91 Processing Path Forward Timeline is provided in Section 6.0 of this report and is illustrated in an overall M-91 Waste Inventory "work-off" diagram (Figure S.2). Modest near-term annual investments of $\sim \$ 1.5 \mathrm{M}$ in FY 05/ FY 06 and $\sim \$ 8 \mathrm{M}$ in FY07-FY10 are needed to realize the maximum benefit of the new, phased processing approach.
This proposed approach would not only accelerate initiation of the processing of the M-91 waste streams, but would significantly complete the processing mission ahead of the previous baseline and the TPA-mandated processing rates and schedules by nearly a decade.

An estimated life-cycle savings of nearly $\$ 125$ million is predicted. 


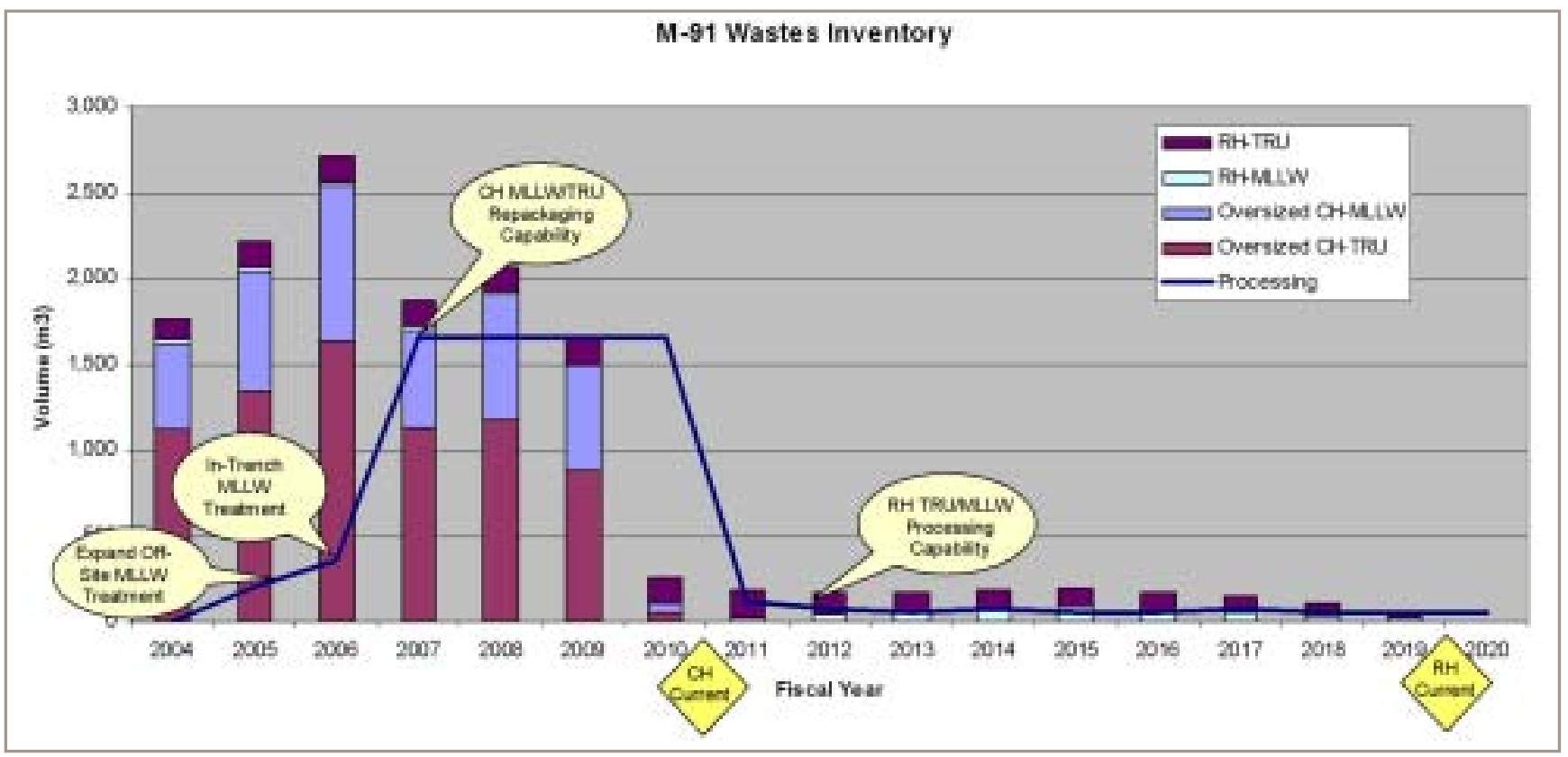

Figure S.2. Accelerated Processing of M-91 Waste 


\section{Contents}

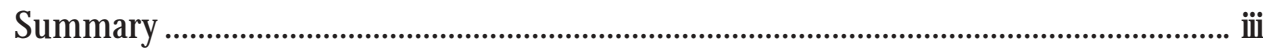

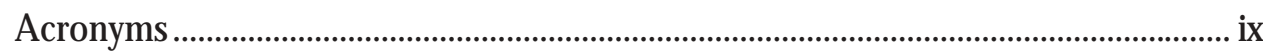

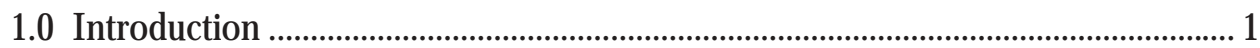

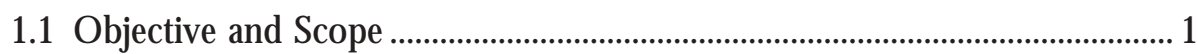

1.2 Background .......................................................................................................... 2

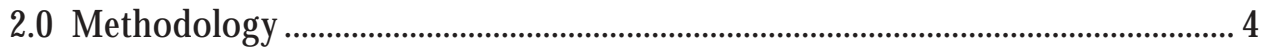

3.0 Existing Capabilities and M-91 Waste Estimates .................................................... 6

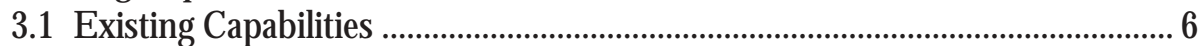

3.1.1 Existing TRU Storage/ Processing Capabilities ....................................... 6

3.1.2 Existing MLLW Storage/ Treatment Capabilties ........................................ 8

3.2 Predicted Waste Volumes .................................................................................. 8

3.3 Uncertainties .................................................................................................... 10

3.4 Waste Disposition Capabilities Required ............................................................ 10

3.4.1 Waste Disposition Functional Requirements ......................................... 11

3.4.2 Current Technical Baseline ............................................................................ 11

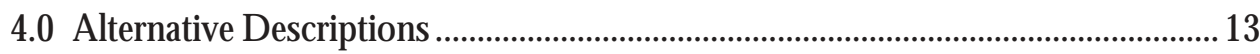

4.1 Augment Existing Capabilties to Accelerate Near-Term Processing ........... 14

4.2 Longer-Term RH Waste Processing Capabilities ................................................. 16

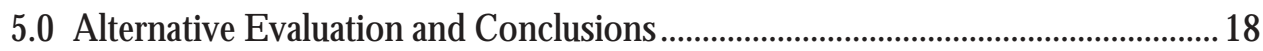

5.1 Near-Term Actions ........................................................................................... 18

5.2 Longer-Term Actions for RH Waste ........................................................... 19

5.3 Life-Cycle Cost Comparisons ............................................................................. 20

6.0 Recommendations and Path Forward …...............................................................22

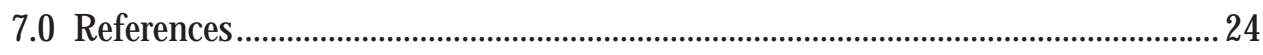

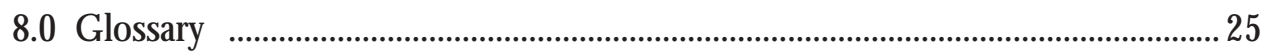

9.0 Acknowledgments ................................................................................................... 30

Appendix A - Current Capabilities of the T Plant Complex ...................................... 31

Appendix B-M-91 Waste Volume Forecasts ............................................................... 32

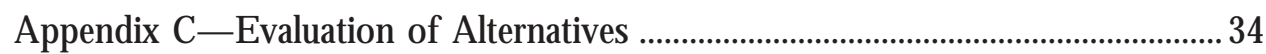

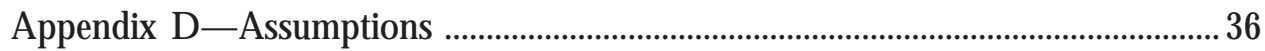

Appendix E-Accelerated M-91 Cost Evaluation ...................................................... 39 


\section{Figures}

S.1 M-91 Waste Conceptual Processing Flow Diagram .................................................. iii

S.2 Accelerated Processing of M-91 Waste ........................................................................ vi

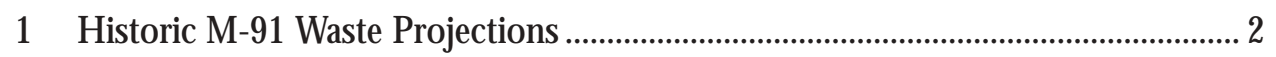

2 233-S D \&D O perations ......................................................................................... 3

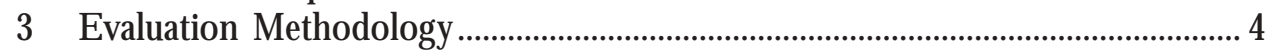

4 Determination of M-91 Waste Volumes ................................................................ 6

5 Hanford's Primary TRU and MLLW Storage Facilities ......................................... 7

6 Hanford's WRAP Facility ........................................................................................ 7

7 Hanford's T Plant ................................................................................................ 7

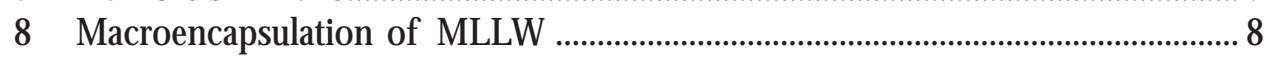

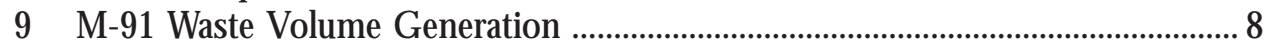

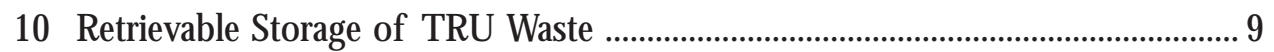

11 M-91 Waste Volume Projections .............................................................................. 9

12 Recent Changes in Waste Volume Projections ....................................................... 10

13 M-91 Waste Inventory Using the Minimum TPA Processing Rates .................... 12

14 M-91 Processing Evaluation Approach ........................................................................ 13

15 Temporary Containment Structures ................................................................... 16

16 Processing of Oversized CH Waste .................................................................... 18

17 Processing of RH Waste ........................................................................................... 19

18 Existing Planning Cost Basis for the M-91 Processing Mission ............................. 20

19 Accelerated Planning Costs Basis for the M-91 Processing Mission .................... 21

20 Potential Cost Savings Associated with the M-91 Acceleration Approach ........ 21

21 Proposed M-91 Processing Path Forward Timeline ................................................. 23

B.1 Annual Waste Generation Projections .................................................................... 32

B.2 Oversized Contact-Handled TRU Waste Forecasts from SWIFT Database .... 33

B.3 Remote-Handled TRU Waste Forecasts from SWIFT D atabase ......................... 33

\section{Tables}

S.1 M-91 Waste Stream Forecasts and Preferred Alternative Processing Approach and Assumptions ................................................................................... iv

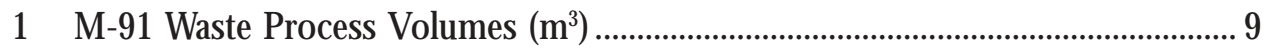

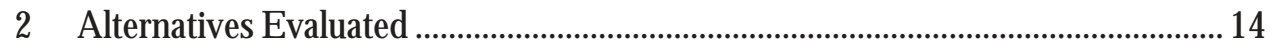

A.1 Current Capabilities of T Plant Complex ………................................................. 31

B.1 Historic Waste Volume Forecasts .......................................................................... 32

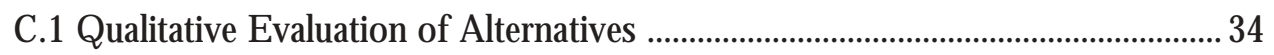

D.1 Proposed Waste Volume Processing Scheme ........................................................... 36

E.1 Cost Savings Summary ............................................................................................. 39

E.2 Proposed M-91 Accelerated Processing Approach ..................................................... 39

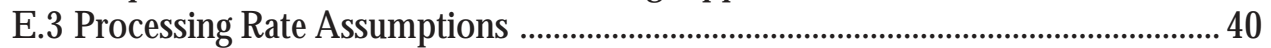

E.4 Adjusted D ecember 2003 Baseline Costs .............................................................. 40 


\section{Acronyms}

APL

$\mathrm{CH}$

CWC

$\mathrm{D} \& \mathrm{D}$

DOE

ERDA

ES

FDC

FHI

FMEF

FY

HSSWAC

HSWEIS

LD R

LLBG

LLCE

MASF

MLLW

NDA

NDE

ORP

PNNL

PUREX

$\mathrm{RH}$

RL

ROD

SWIFT

SWB

TPA

TRU

WAC

WIPP

WRAP accelerated process line

contact-handled

Central Waste Complex

decontamination and decommissioning

U.S. D epartment of Energy

U.S. Energy Research and Development Administration engineering study

Functional Design Criteria

Fluor Hanford, Inc.

Fuel \& Materials Examination Facility

fiscal year

Hanford Site Solid Waste Acceptance Criteria

Hanford Solid Waste Environmental Impact Statement

Land Disposal Restriction

Low Level Burial Ground

long-length contaminated equipment

Materials and Storage Facility

mixed low-level waste

non-destructive assay

non-destructive examination

(U.S. D epartment of Energy) Office of River Protection

Pacific Northwest National Laboratory

Plutonium-Uranium Extraction Facility

remote-handled

U.S. D epartment of Energy, Richland O perations Office

Record of Decision

Solid Waste Integrated Forecast Technical (database)

standard waste box

Tri-Party Agreement (Hanford Federal Facility Agreement and Consent O rder)

transuranic

Waste Acceptance Criteria

Waste Isolation Pilot Plant

Waste Receiving and Processing Facility 



\subsection{Introduction}

\subsection{Objective and Scope}

The objective of this evaluation is to identify and evaluate viable alternatives for the accelerated processing of Hanford Site transuranic (TRU) and mixed low-level wastes (MLLW) that cannot be processed using existing capabilities. The limited existing processing capabilities include:

- The use of both offsite contracts and onsite facilities for treating MLLW prior to compliant disposal onsite, covering $\sim 93 \%$ of the predicted MLLW volumes.

- The use of the Waste Receiving and Processing Facility (WRAP), the T Plant Complex, and mobile TRU waste processing units for the processing and certification of the TRU waste prior to shipment to the Waste Isolation Pilot Plant (WIPP) for disposal, covering 78\% of the predicted TRU Waste Volumes.

The processing need is to handle both oversized MLLW and TRU containers as well as containers with surface contact dose rates greater than $200 \mathrm{mrem} / \mathrm{hr}$ (referred to as remote handled [RH] waste). This capability is known as the "M-91" processing capability required by Tri-Party Agreement (TPA) milestone M-91-01. Thus the waste to be processed is referred to as "M-91" waste. Over time, the forecasted amount of M-91 waste has been changing and is trending downward. An updated analysis of the waste volumes requiring such processing is provided in Section 3.0. It is this change, along with changes in existing capabilities and a driving desire to accelerate Hanford's cleanup and waste processing tasks, that has led to the need to reexamine the M-91 waste processing plans.

In performing the evaluation of the processing alternatives, the following guiding programmatic goals and principles were employed:

- Select options that accelerate processing of waste in storage (early reduction of, or avoidance of, waste backlog).

- Expand the use of existing onsite capabilities, commercial capabilities, or limited capability upgrades to reduce the capital cost and schedule impacts associated with new processing facilities or modules.

- Continue to gain experience and practical knowledge in the repackaging and processing of contact-handled $(\mathrm{CH})$ waste prior to embarking on the processing of the more difficult and hazardous $\mathrm{RH}$ waste streams. This allows progress to be made while solving the more difficult problems associated with the high dose rate waste.

- Ensure all capabilities needed are identified and planned for the processing of the M-91 waste (no identified gaps) and that there is flexibility (backup capability) where possible.

- Optimize the use of recommended facilities/ capabilities to avoid workforce impacts (e.g., cycling of resource needs due to high variations in processing rates and requirements) and the associated cost inefficiencies.

- Select options that accelerate completion of the overall processing program and enable the earliest possible shutdown of individual facilities/ capabilities.

The aim of this evaluation is to develop a preferred M-91 processing approach and associated path forward to provide a basis for program planning and needed follow-on engineering evaluations.
The objective of this evaluation is to identify and evaluate viable alternatives for the accelerated processing of Hanford Site transuranic (TRU) and mixed low-level wastes (MLLW) that cannot be processed using existing capabilities. 


\subsection{Background}

As the programs that generate or process waste have matured, waste volume forecasts from these programs have been updated to reflect this understanding.

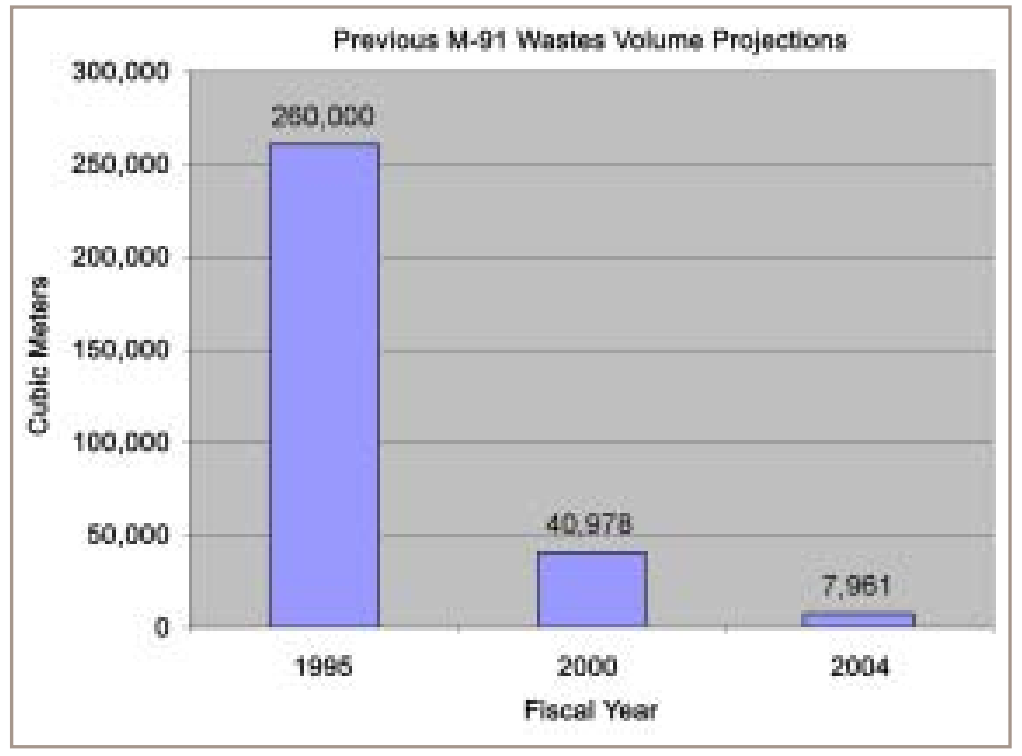

Figure 1. Historic M-91 Waste Projections
These changes are consistent with Hanford's life-cycle baseline planning assumptions (D OE 2002). D uring the past few years waste volume projections requiring M-91 capabilities have significantly decreased. (a) While it is difficult to directly compare previous forecast details, Figure 1 illustrates the dramatic changes that have occurred over the past decade. Some of the reasons for these changes are:

- Changes to the Waste Acceptance Criteria (WAC) requiring forecasted wastes to be packaged consistent with treatment capabilities. This change was driven by Hanford's Solid Waste Program as a means to minimize generation of problematic waste streams.

- Treatment and processing capabilities have expanded.

- Generators will be sending MLLW directly to commercial treatment units or treating MLLW at the point of generation, thus reducing the amount of newly generated waste requiring " $\mathrm{M}-91$ " processing.

- Generators have also been aggressively implementing waste minimization and pollution prevention programs aimed at further reducing waste volumes from routine operations and ensuring that wastes produced are packaged in a size and manner to allow direct disposition.

- Tank farm closure activities are producing MLLW that had been previously forecast as TRU waste.

During the past few years waste volume projections requiring M-91 capabilities have significantly decreased.
- The Plutonium Finishing Plant has made advancements in its planning for glove box decontamination and decommissioning (D\&D) and waste packaging that have reduced the forecasted amount of TRU waste generation.

- All post-1970 retrievably stored suspect TRU waste must be retrieved, and all non-TRU waste is now assumed to be MLLW and will be segregated and treated to meet applicable federal and state land disposal restriction (LDR) standards. This has lead to an increase in M-91 MLLW volume.

These changes and changes in the M-91 milestones, have allowed processing alternatives that address specific wastes to become more attractive as compared with pursuing a single facility capable of handling all RH and large-container waste. Previous studies that evaluated processing alternatives include the Solid Waste and M aterials Systems A lternatives Study (WHC 1995) and the Trade Study for the Prooessing,

(a) Waste volume projections are described in greater detail in Section 3.0. Historic waste volume projections were obtained from previous studies. Current waste volume projections are obtained from the Solid Waste Integrated Forecast Technical (SWIFT) database, current as of D ecember 2003 and inventory records. 
Treatment, and Storage of H anford Site Solid Waste Streams That H ave N 0 C urrent Path Forward (WMFS 1998). These studies, along with Site Schedule Options Studies conducted in FY01, indicated use of an existing permitted facility (T Plant Complex) would be significantly less expensive than the design, construction, startup, and $\mathrm{D} \& \mathrm{D}$ of a new facility (capital cost of approximately $\$ 100 \mathrm{M}$ for upgrading the existing facility versus $\$ 350 \mathrm{M}$ for a new facility).

O ther examples of programmatic and technical progress that influence the evaluation include:

- New M-91 change package milestones accelerate the requirements for some M-91 capabilities.

- Hanford has worked with commercial treatment services to expand commercial processing capabilities to augment the strategy for Hanford Site MLLW. Prior to this effort, there was limited offsite capability for RH MLLW or CH MLLW in packages larger than $5 \mathrm{ft} \times 5 \mathrm{ft} \times 9 \mathrm{ft}$. O ffsite capability is currently being evaluated for some RH MLLW, perhaps up to $500 \mathrm{mrem} / \mathrm{hr}$ and up to $10 \mathrm{~m}^{3}$ for larger packages.

- The 233-S Building was contaminated with plutonium, but was demolished using aggressive contamination control measures (Figure 2). This experience suggests that some large packages of material might be processed in temporary enclosures at the point of generation with similar aggressive contamination control measures. In addition, experience with temporary enclosures at the 222-S facility could also be applied in conjunction with existing processing facilities to provide an economical solution for the processing of the largest waste packages.

It should be noted that a potentially significant volume of waste may be generated as a result of implementation of future cleanup decisions, where formal records of decision (RODs) have not yet been reached. Such potential waste volumes are not included in current forecasts, and include sources such as the PUREX Tunnels, the Pre-1970 LLW burial

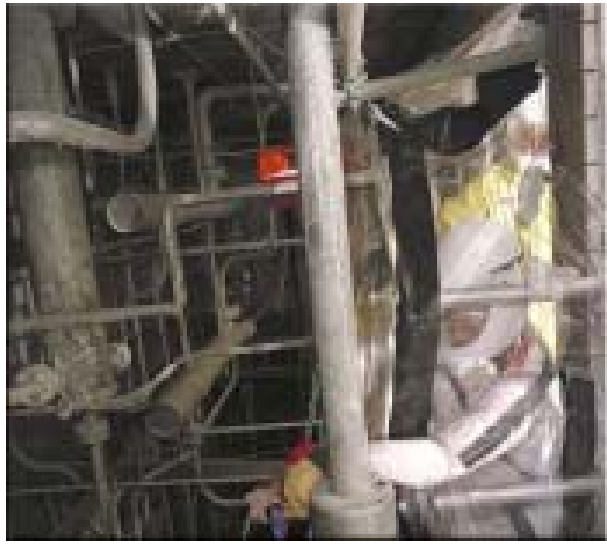

Figure 2. 233-S D\&D Operations grounds, extensive D \&D of canyons and other 200 Area facilities, and various tank closure options. In addition, the risk-based end state processes currently under way could also drastically alter the timing and makeup of waste volumes requiring M-91 processing capabilities.

It is for these reasons a flexible planning basis is needed to ensure that capabilities can be adapted as program changes are encountered. Most of the remedial decisions that will influence such changes will be made over the next four years. Impacts from these decisions could significantly alter the M-91 forecasts, resulting in potential order of magnitude changes. TPA Milestones M-016-93 (Ecology 2004) requires submission of an implementation workplan by September 30, 2006 to reflect cleanup decisions and the resulting projected waste volumes. This plan will be updated in FY09 and FY 12.

A potentially significant volume of waste may be generated as a result of implementation of future Hanford cleanup decisions. 
This report is not intended to replace the follow-on engineering studies that are needed to formally establish design criteria and cost estimates, but merely to aid in focusing the content of those studies on the most desirable options.

\subsection{Methodology}

In order to meet the objectives of this evaluation, a simple, step-wise process was developed. This process is illustrated in Figure 3 and is aimed at understanding the sources and characteristics of the waste requiring treatment or processing and the identification and evaluation of a suite of viable alternatives. This report is not intended to replace the follow-on engineering studies that are needed to formally establish design criteria and cost estimates, but merely to aid in focusing the content of those studies on the most desirable options.

The first two steps of the process are to identify, describe and bin the waste steams requiring processing into manageable sub-groups. This is necessary to fully understand what is and what is not included in the M-91 waste streams, and which streams dominate the profile and when they are produced. Second, existing capabilities that can be applied to portions of these waste volumes will be described and accounted for. The results of these first two steps will be waste volume forecasts and necessary capabilities (by function) that need to be advanced on to the subsequent evaluation phases. This portion of the evaluation defines the scope of the subsequent analyses and is included in Section 3.0.

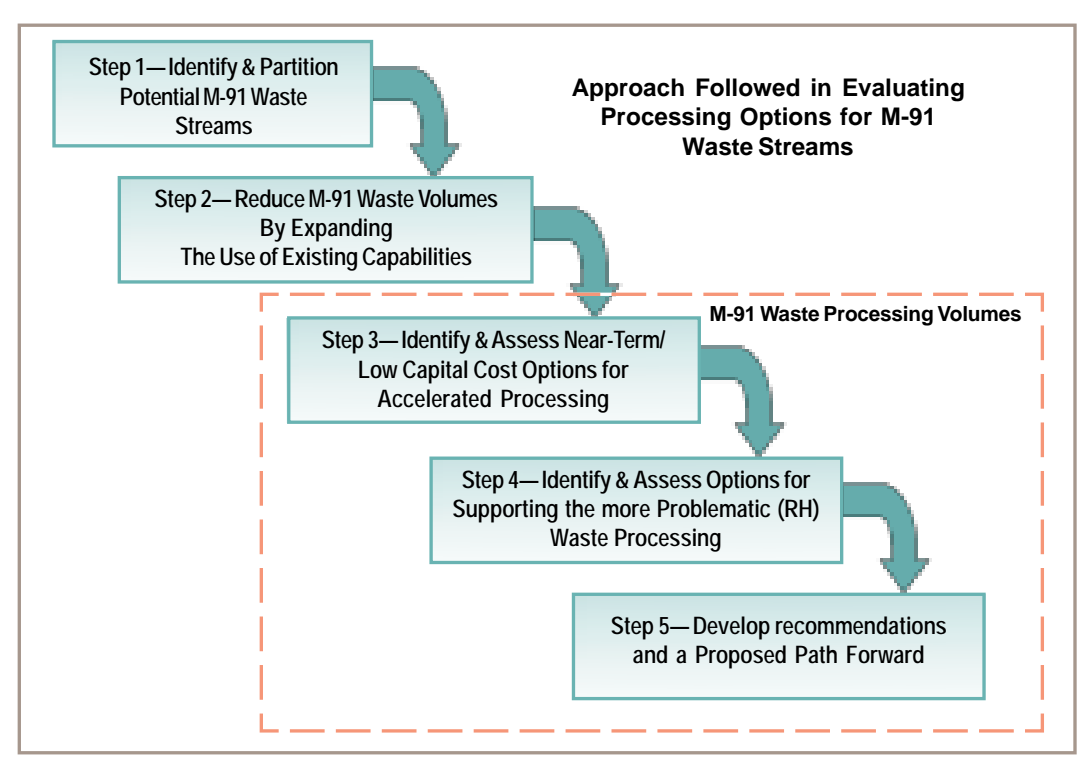

Figure 3. Evaluation Methodology

The evaluation of alternative processing options for the identified M-91 waste volumes will be conducted in the next two steps of the evaluation process. The third step of the evaluation process will be to identify processing and treatment options that maximize the use of existing capabilities and contracts, require minimal capital investments, and are aimed at accelerating the processing of wastes currently in inventory. This phase will be predominately aimed at the oversized contact handled (CH) MLLW and TRU waste with only a small fraction of the more problematic $\mathrm{RH}$ waste being addressed. Alternatives will be described and evaluated. The evaluation will consider the advantages and disadvantages for each alternative, using the following attributes as discriminators:

- Cost Implications.

- Schedules Constraints.

- Worker Health \& Safety.

- Regulatory Acceptability.

Alternatives deemed non-viable will be dismissed from further consideration. Much of the information used in this evaluation will be from previous engineering studies and may be qualitative or semi-quantitative in nature. 
The fourth step in the evaluation process begins with the description of the waste volumes that cannot be addressed using existing or augmented capabilities and require fundamentally new processing options. The possible suite of facility alternatives that could support those remaining capability needs will be identified and evaluated using the same approach and evaluation criteria as described above. Both the third and fourth step of the evaluation process are described in Section 4.0.

The final step in the evaluation process will be the development of recommendations and a path forward to provide a basis for program planning and needed follow-on engineering evaluations. Section 5.0 contains a comparison of the recommended strategies to the existing baseline. Based on these conclusions, Section 6.0 provides recommendations for proceeding with the implementation of a new, phased processing approach.
The final step in the evaluation process will be the development of recommendations and a path forward to provide a basis for program planning and needed follow-on engineering evaluations. 


\subsection{Existing Capabilities and M-91 Waste Estimates}

This section provides a description of existing capabilities for the treatment and disposal of MLLW and for the processing, certification, and disposition of TRU waste. Predicted waste volumes and their generation/ retrieval over time are provided for those waste streams that cannot be processed using existing capabilities. These waste volume estimates form the basis for the M-91 capability needs. This section also contains a brief description of the uncertainties associated with these waste volume estimates, as well as a description, by function, of the capabilities needed to store, process/ treat, and disposition the M-91 waste volumes.

\subsection{Existing Capabilities}

Figure 4 provides a summary of the existing capabilities for the storage, treatment, and processing of MLLW and TRU waste and illustrates the resulting M-91 waste volumes.

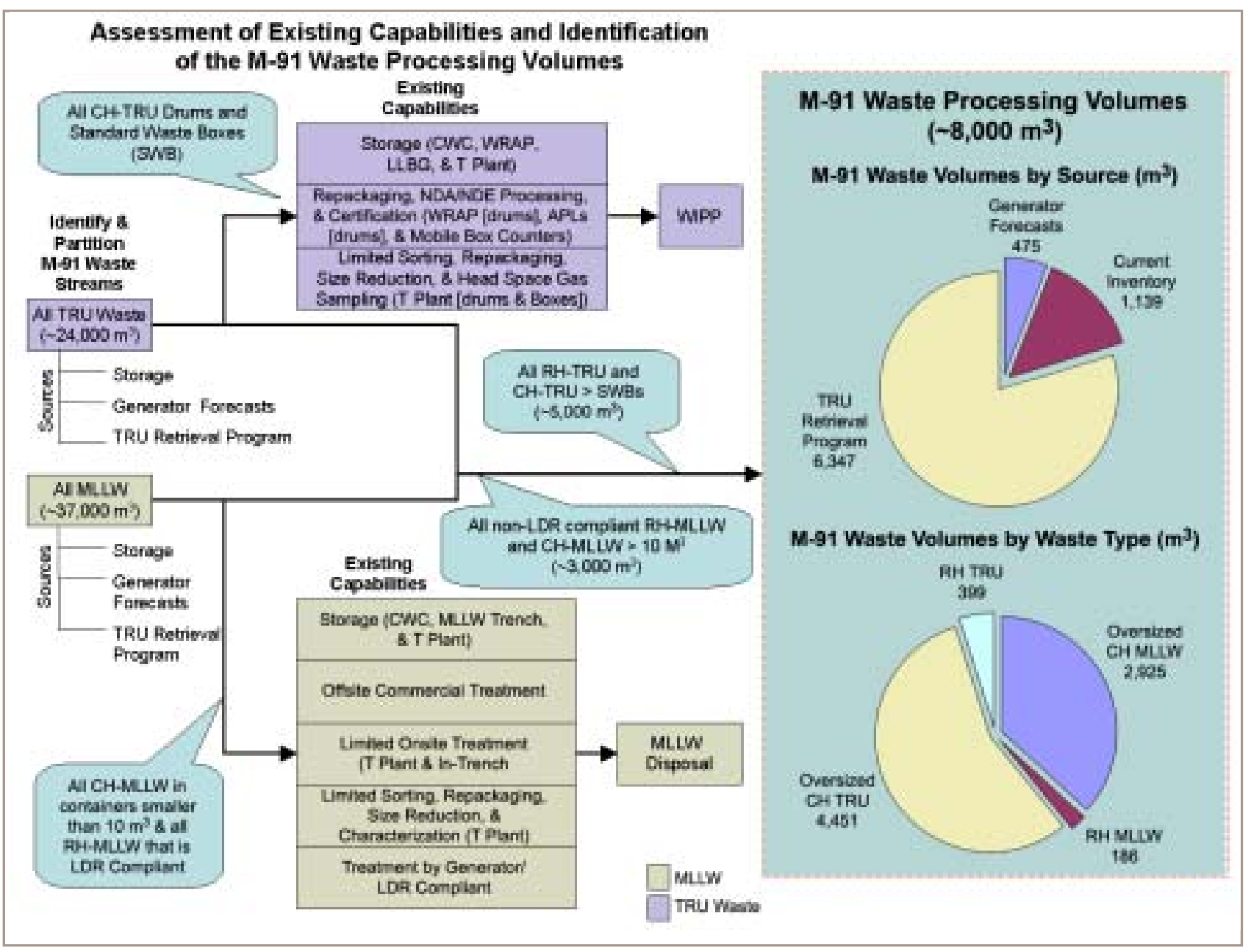

Figure 4. Determination of M-91 Waste Volumes

\subsubsection{Existing TRU Storage/Processing Capabilities}

TRU waste is currently stored within the Central Waste Complex (CWC), at the WRAP facility, within the Low Level Burial Grounds (LLBG) (retrievably stored), and at the $\mathrm{T}$ Plant canyon. Figure 5 provides a number of photographs of Hanford's waste storage operations. 


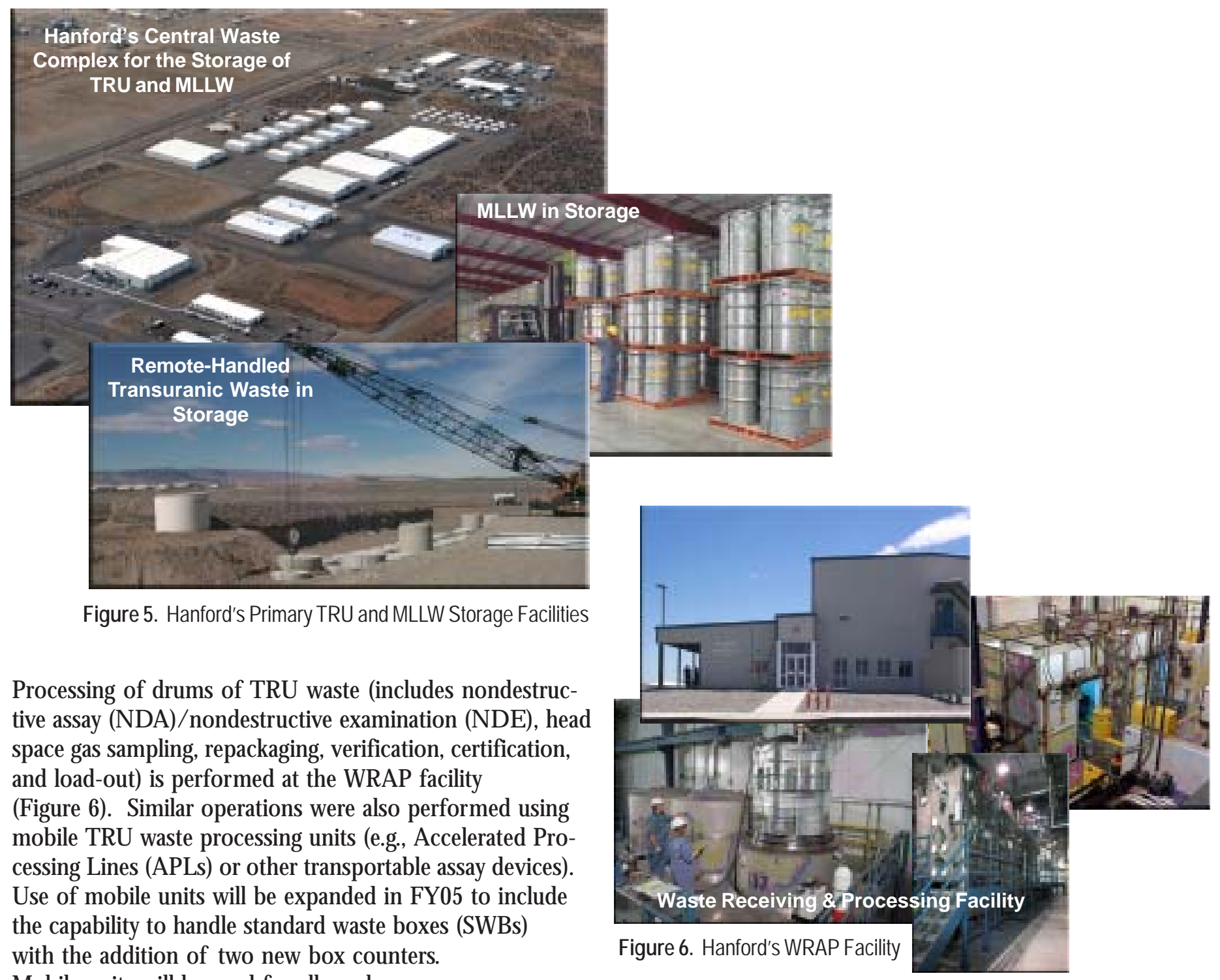

Mobile units will be used for all newly generated $\mathrm{CH}-\mathrm{TRU}$ drums and SWBs after WRAP is shut down in 2012.

In addition to the storage of remotehandled TRU and MLLW, T Plant Complex (Figure 7) is also currently used on a limited basis to support waste sampling and characterization, repackaging, and segregation of $\mathrm{RH}$ and $\mathrm{CH}$ TRU wastes. In addition, the 2706-T facility is used to augment WRAP and the APLs by conducting head space gas sampling activities. Appendix A provides additional details surrounding the T Plant Complex's current capabilities and uses.

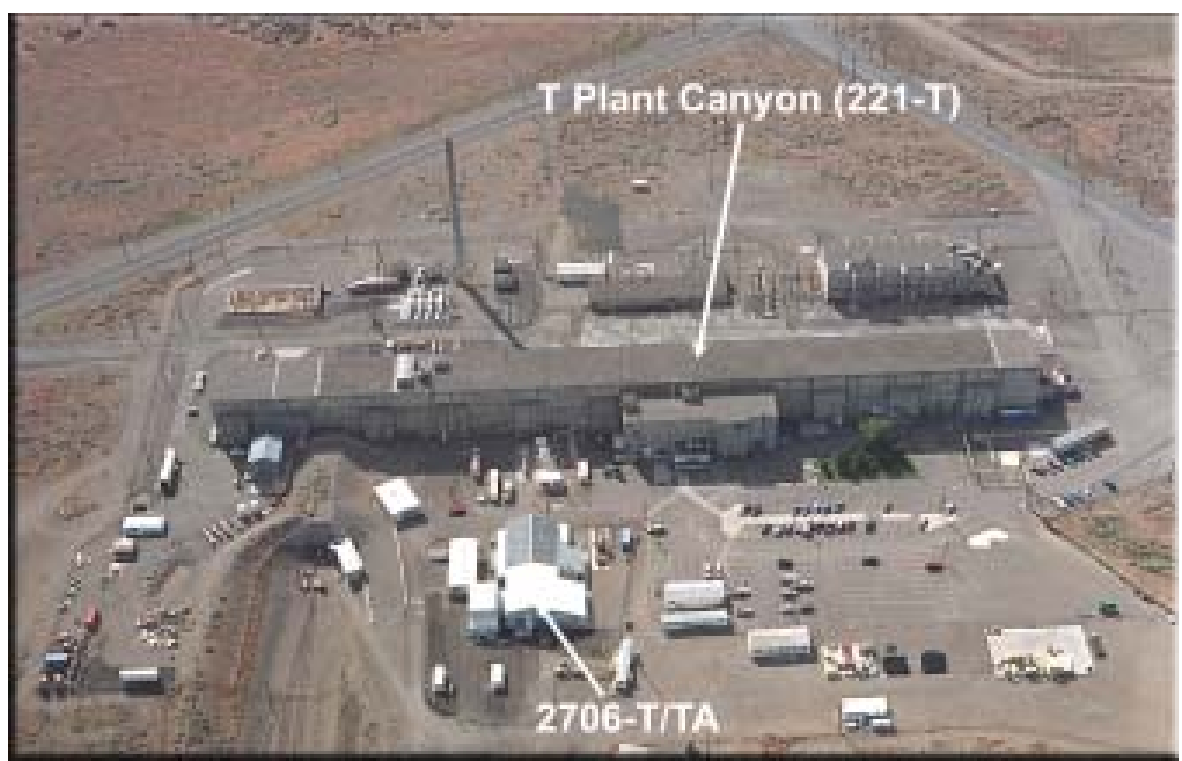

Figure 7. Hanford's T Plant 


\subsubsection{Existing MLLW Storage/Treatment Capabilities}

MLLW, like TRU waste, is primarily stored within Hanford's CWC facility (Figure 5). In addition, RH MLLW is also stored at the T Plant Canyon. The treatment of MLLW is primarily accomplished through a series of offsite commercial contracts (e.g., PEcoS, PermaFix). In general, these contracts were set up to handle contact-handled waste for drums and boxes smaller than 6 cubic meters ( $5 \mathrm{ft}$ x $5 \mathrm{ft}$ x $9 \mathrm{ft}$ box). However, they have been used on a case-by-case basis to deal with larger containers up to 14 cubic meters. Contract modifications are currently being pursued to allow for the routine shipment of waste in containers up to 10 cubic meters ( $6 \mathrm{ft} \times 6 \mathrm{ft}$ x $10 \mathrm{ft}$ box).

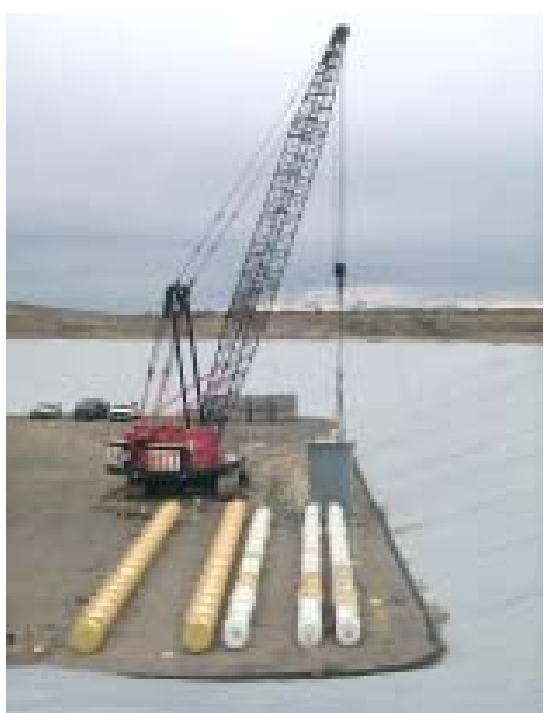

Figure 8. Macroencapsulation of MLLW

On a limited basis, onsite treatment (primarily macroencapsulation) is conducted. In addition to treatment by generator, treatment has also been performed at the T Plant Complex. As an example, long-length contaminated equipment (LLCE), which consists of equipment more than 12 feet long that is removed from underground waste tanks (e.g., mixer pumps, transfer pumps, air lances, and monitoring equipment), is being macroencapsulated and disposed into one of Hanford's MLLW D isposal Units (LLBG 218-W5 T31/ T34). The macroencapsulation of LLCE began in CY 1996 and was originally performed at the T Plant Complex. Since then, treatment has been done under the Treatment-byG enerator provisions and shipped directly to the disposal unit (Figure 8). Such treatment is also performed on a limited basis within Hanford's disposal trenches. For example, MLLW is treated within the boundaries of the Environmental Restoration D isposal Facility, and Greater than Category 3 Low Level Waste is treated in a similar manner within the LLBGs.

The T Plant Complex is also used to sort, characterize, size reduce, and repackage MLLW. Such operations allow for the waste to be placed in standard container sizes that can be shipped to the offsite commercial treatment providers. Operations such as these are typically required to be performed at the T Plant Complex in cases where there is unknown or questionable inventory or items present in the waste that commercial treatment providers cannot accept.

\subsection{Predicted Waste Volumes}

Waste that cannot be currently treated/ processed using the existing Hanford Site capabilities described above will form the basis for the M-91 waste processing

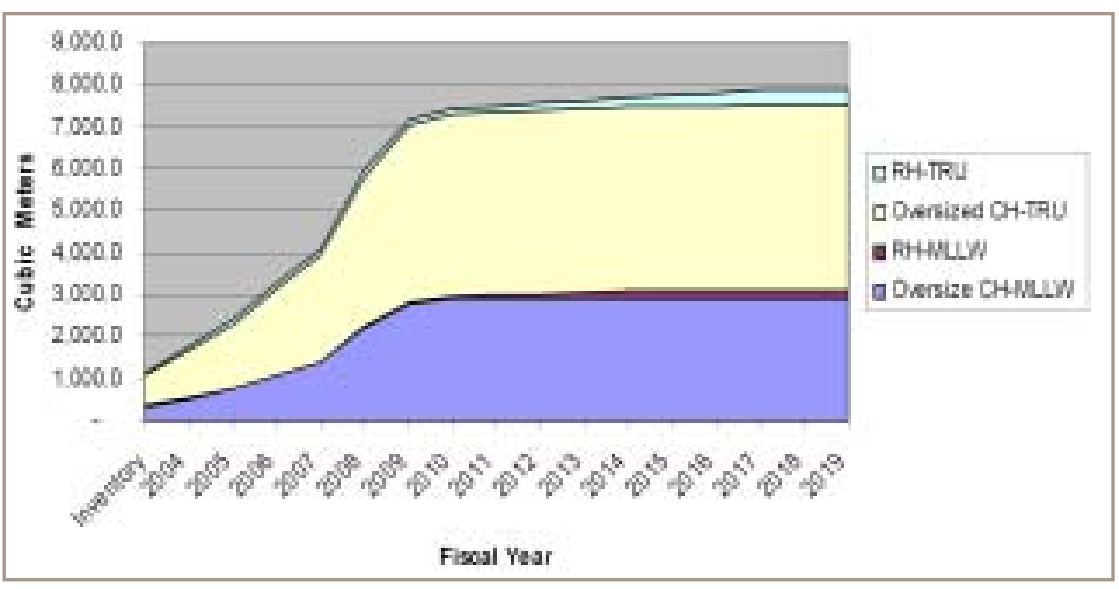

Figure 9. M-91 Waste Volume Generation volumes. Appendix B contains the output from the SWIFT database for all RH MLLW and TRU waste as well as for oversized MLLW (in containers greater than $10 \mathrm{~m}^{3}$ ) and oversized TRU waste (in containers larger than an SWB). The projected waste volumes, over time, are provided in Figure 9. Table 1 groups the predicted waste volumes into three primary sources: generator forecasts, current inventory, and waste associated with the TRU Retrieval Program. 
Table 1. M-91 Waste Process Volumes $\left(\mathrm{m}^{3}\right)$

\begin{tabular}{|l|c|c|c|c|c|}
\hline & $\begin{array}{c}\text { Oversized } \\
\text { CH-MLLW }\end{array}$ & $\begin{array}{c}\text { RH- } \\
\text { MLLW }\end{array}$ & $\begin{array}{c}\text { Oversized } \\
\text { CH-TRU }\end{array}$ & RH-TRU & Total \\
\hline GeneratorForecasts & 0 & 6 & 199 & 270 & 475 \\
\hline Current Inventory & 311 & 27 & 751 & 50 & 1,139 \\
\hline T RU Retrieval Program & 2,614 & 153 & 3,501 & 79 & 6,347 \\
\hline Total & 2,925 & 186 & 4,451 & 399 & 7,961 \\
\hline
\end{tabular}

From the forecast data, a number of relevant conclusions can be drawn. The bulk of the M-91 waste that requires processing is the oversized contact-handled TRU waste and oversized contacthandled MLLW, which combined represents over $90 \%$ of the total volume to be processed with a significant amount already in inventory/ storage (over 1,000 cubic meters). The predominant source of the M-91 waste is the TRU Retrieval Program (Figure 10) with nearly $80 \%$ of the volume. Oversized and $\mathrm{RH}$ waste coming out of the TRU Retrieval Program may require processing before a determination can be made on whether the waste is MLLW or TRU waste. Cargo containers as large as 40-ft long are included within this program and

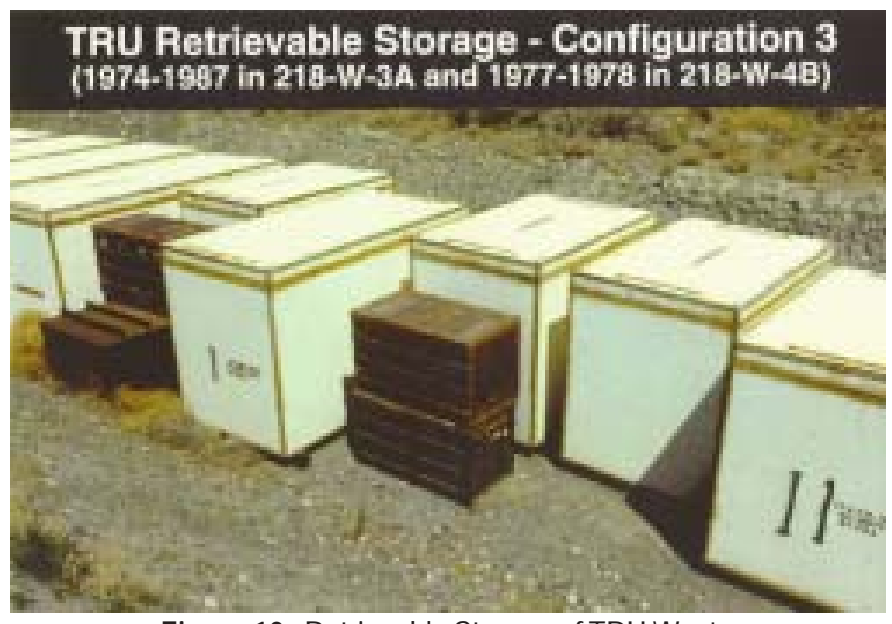

Figure 10. Retrievable Storage of TRU Waste represent some of the largest containers that will require processing. In cases where existing containers (such as wooden and fiberglass reinforced boxes or aging drums) have become breached or unstable, efforts will be made, to repackage the material in the trench into more standard size containers to facilitate the downstream treatment/ processing.

Figure 11 illustrates the relative contribution to the M-91 waste volumes from these primary sources and by waste type. Appendix B also provides a number of graphs summarizing the predicted waste volumes over time. The TRU Retrieval Program is currently scheduled to complete retrieval operations for CH-TRU by 2010, for boxes and drums of RH-TRU by 2015, and of the RH-TRU stored in under-
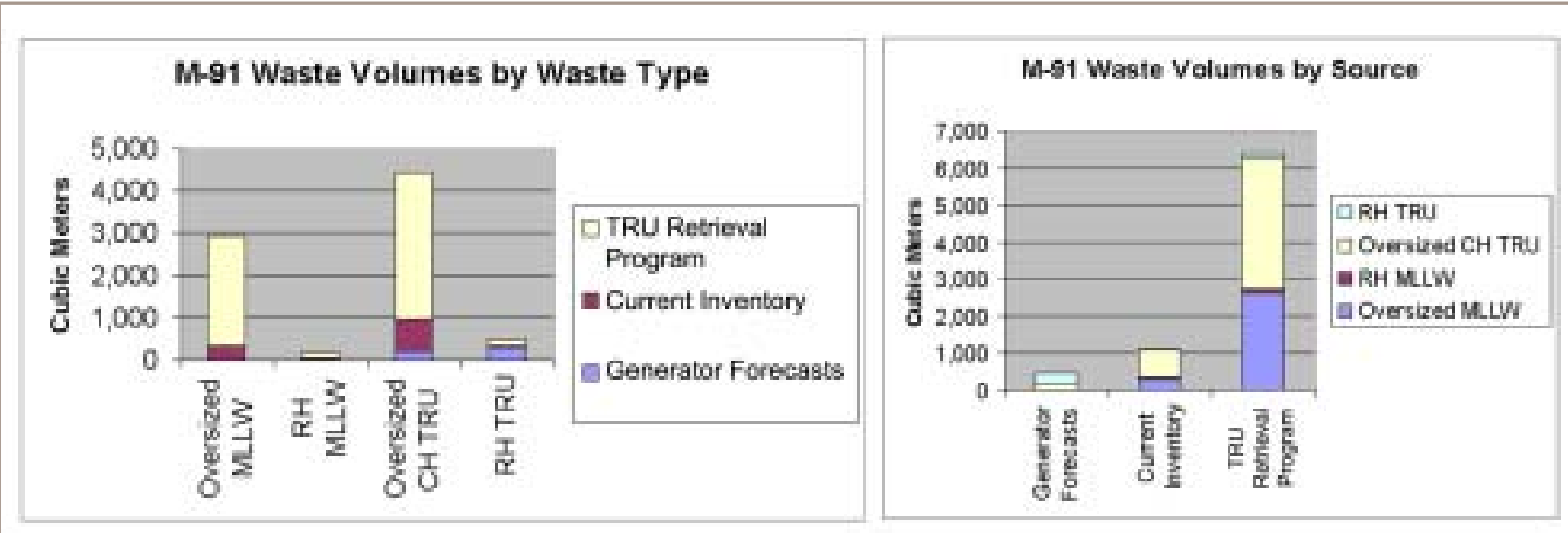

Figure 11. M-91 Waste Volume Projections 
In general, the trend in waste volumes has been downward with current estimates considerably lower than previous estimates.

ground caissons by 2018. The next largest contributor to out-year waste forecasts is the RH-TRU waste projected to come from the 618-10/ 11 burial ground remediation, which is scheduled to begin in 2013 and be completed by 2017. Very little M-91 MLLW is included in the generator forecasts. M-91 TRU waste volume projections beyond 2017 are relatively small and are all associated with the O ffice of River Protection (ORP) tank closure activities.

O ther radioactive wastes and materials, including K-Basin sludge, routine LLW, liquid wastes, cesium and strontium capsules, plutonium materials, spent nuclear fuel, environmental restoration wastes (except the predicted TRU waste coming from the 618-10/ 11 burial ground remediation), and tank waste are outside the scope of this evaluation and are not expected to be processed or treated using the M-91 capabilities.

\subsection{Uncertainties}

Figure 12 illustrates recent changes in waste volume projections over the past few years. In general, the trend has been downward with current estimates considerably lower than previous estimates. In 2000

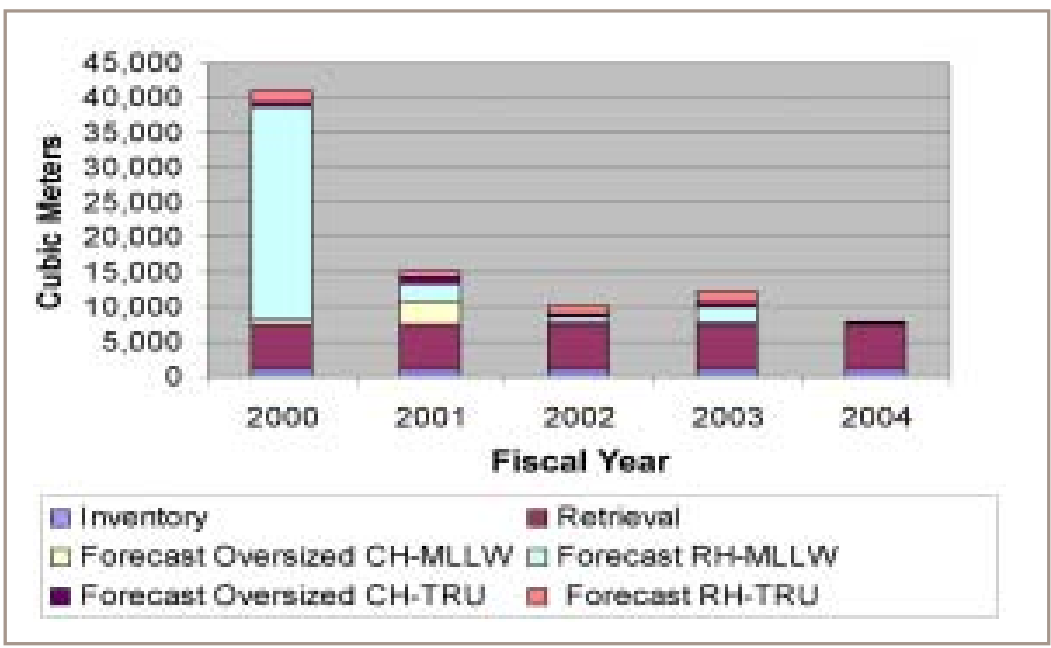

Figure 12. Recent Changes in Waste Volume Projections (and earlier) the waste forecast did not identify MLLW that was LD R-compliant, thus the forecast in 2000 included all oversized $\mathrm{CH}$ and all RH MLLW forecast (whether ready for immediate disposal or requiring treatment). In addition, long-length equipment from the high-level waste tanks is no longer included in the forecast since it is assumed that these items will either undergo treatment-by-generator or will be closed in place.

However, as was previously noted, a potentially significant volume of waste may be generated as a result of implementation of future cleanup decisions.

Such potential waste volumes are not included in current forecasts, and include sources such as the PUREX Tunnels, the Pre-1970 LLW burial grounds, extensive D \&D of Canyons and other 200 Area facilities, and various tank closure options. Recently established TPA Milestone M-016-93 requires D OE to submit an implementing workplan in September 2006 to EPA for the acquisition of capabilities necessary to prepare TRU and TRUM waste generated by CERCLA cleanup actions for shipment to WIPP (Ecology 2004). In addition, the risk-based end state processes currently underway could also drastically alter the timing and makeup of waste volumes requiring M-91 processing capabilities. Other potential factors influencing these forecasts include the ability of generators to accurately forecast their predicted waste streams, along with their ability to treat to LDR standards and package into containers suitable for processing with existing facilities.

\subsection{Waste Disposition Capabilities Required}

The following subsections describe the individual capabilities or functions that are needed to allow for the final disposition of the M-91 waste streams. Some of these functions will be used in conjunction with existing capabilities. Following the 
description of the needed capabilities, a summary of the existing technical baseline and the M-91 settlement agreement is provided.

\subsubsection{Waste Disposition Functional Requirements}

M-91 capabilities that will need to be provided for oversized CH-TRU include:

- Sorting/ repackaging

- Size reduction

- Solidification/ neutralization

- Visual verification

Once the waste is verified and repackaged into drums or SWBs, the remaining NDE/ NDA and certification steps can be completed by the WRAP facility or the mobile processing units.

M-91 capabilities that will need to be provided for RH-TRU include all the capabilities listed above for the oversized CH-TRU along with the following:

- NDA/NDE

- Head Space Gas Sampling(a)

- Certification/ Load-out

All TRU waste will be disposed at the WIPP, near Carlsbad, New Mexico. Certification to the requirements of the WIPP waste acceptance criteria (WAC) is required prior to shipping the waste. The RH-TRU WAC have not yet been established. It is expected that these criteria will not be issued until calendar year 2005/ 2006. At this time, the only approved shipping casks for RH-TRU waste is the RH-72-B cask, which is currently limited to three 55-gallon drums.

MLLW will be treated to meet land disposal restrictions (LDR). M-91 capabilities that will need to be provided for MLLW include:

- Sorting/ repackaging

- Size reduction

- D econtamination/ neutralization

- Stabilization

- Macro-encapsulation

In some cases, all that will be necessary will be sorting and repackaging the waste into containers that can be sent offsite for treatment. This approach will be required for the fraction of MLLW that cannot be treated using macro-

encapsulation and requires thermal or other alternative treatment method.

\subsubsection{Current Technical Baseline}

The current baseline includes modification of an existing facility (221-T Canyon), and/ or the use of modular process systems within that facility, to provide a broad suite of processing capabilities for $\mathrm{CH}$ and RH-TRU waste and MLLW. Under this baseline, full capabilities were originally scheduled to begin no earlier than FY 08
The current baseline includes modification of an existing facility (221-T Canyon), and/or the use of modular process systems within that facility, to provide a broad suite of processing capabilities for $\mathrm{CH}$ and $\mathrm{RH}$ TRU waste and MLLW.

(a) As determined to benecessary by the WIPP RH-TRU WAC. 
for MLLW and FY13 for TRU waste and continue through FY32. This processing option is included as the preferred alternative in the recently approved Final Hanford Site Solid Waste Environmental Impact Statement (D OE 2004).

However, the recent M-91 settlement agreement (see Ecology 2004) has accelerated this schedule. The minimum schedule for obtaining M-91 capabilities is specified by the M-91 agreement. M-91-01 requires all of these facilities/ capabilities to be in place by 6/ 30/ 12. M-91-05-T01 requires the Engineering Study/ Functional Design Criteria Study for these facilities/ capabilities to be completed by 12/31/ 07. This timeframe is intended to allow time for the WIPP WAC RH criteria to be established for use in these studies. In addition, initiation of treatment of $\mathrm{RH}$ and largesize MLLW is required by 6/ 30/ 08 at a rate of $300 \mathrm{~m}^{3}$ per year. Initiation of treatment of $\mathrm{RH}$ and large-size TRU waste is required by 6/30/ 12, at a rate of $300 \mathrm{~m}^{3}$ per year. Using the waste volumes estimated and the required TPA initiation dates and minimum processing rates (e.g., $300 \mathrm{~m}^{3}$ per year) will result in the treatment of all generated and stored MLLW (i.e., no inventory remaining) by 2018 and TRU waste by 2028 (Figure 13).

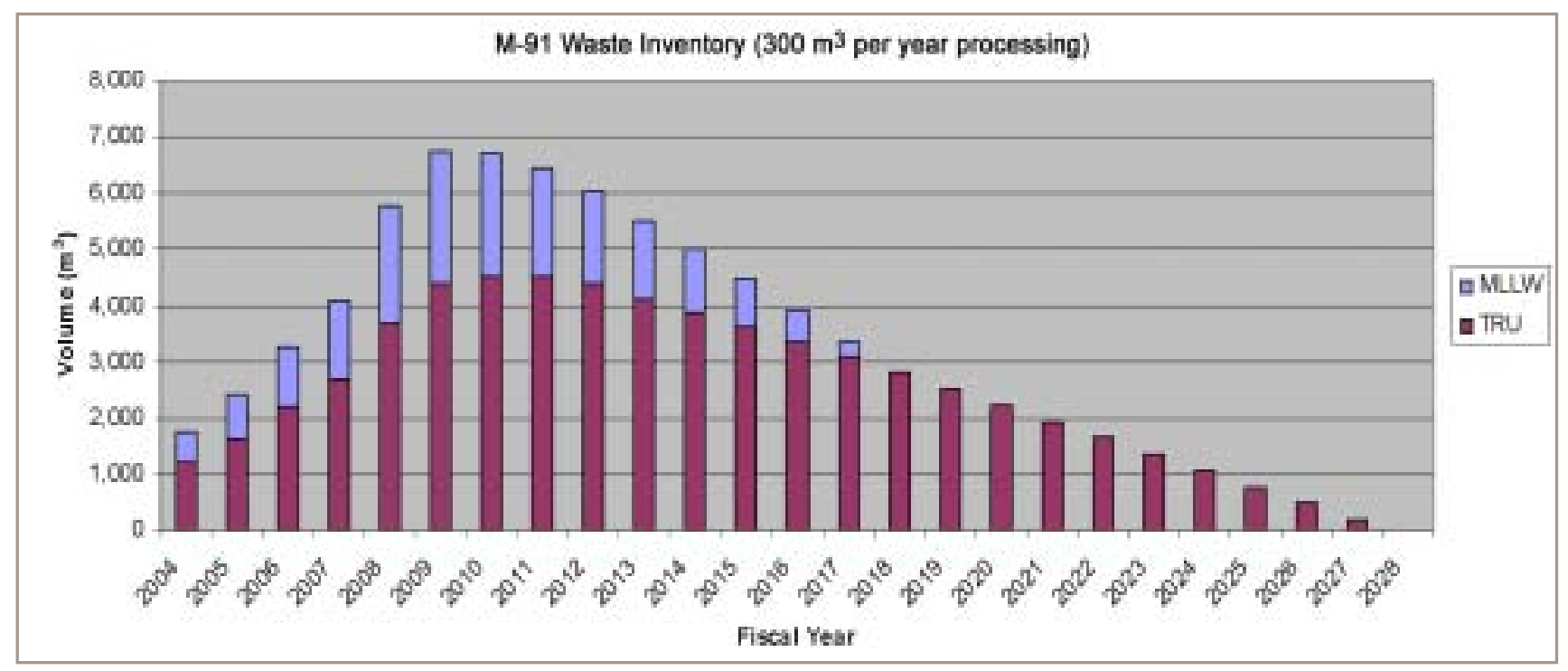

Figure 13. M-91 Waste Inventory Using the Minimum TPA Processing Rates 


\subsection{Alternative Descriptions}

A two-step process is envisioned for acquiring and utilizing the needed M-91 capabilities. The objective of this process will be to "work-off" the backlog (including the waste in storage and being generated) of $\mathrm{CH}$ waste in the next 5 to 6 years, while gaining valuable experience and preparing the way for the more difficult $\mathrm{RH}$ waste streams. The first step will be to rapidly obtain the necessary agreements, contracts, and in-house capabilities needed to address the large volume of oversized CH-MLLW and CH-TRU waste currently in inventory and being generated during the TRU Retrieval Program. The capabilities arising from this step will be a natural extension and augmentation of existing capabilities and will, in fact, be coupled with the ongoing processing of wastes at WRAP and/ or the mobile TRU processing units and with the existing MLLW treatment providers.

The second step will be to evaluate the processing options for the $\mathrm{RH}$ waste streams and other problematic wastes that cannot be processed/ treated through the actions described above. The RH-TRU waste will drive the processing requirements for this step, which cannot be fully developed until WIPP has finalized its RH-TRU WAC. Once the criteria are in place, the objective of this step will be to select the most cost-efficient and timely processing approaches to complete the processing of the $\mathrm{RH}$ waste in an accelerated fashion to allow for the early closure of the processing facility(s). Figure 14 illustrates this process and Table 2 provides a summary of the alternatives considered.

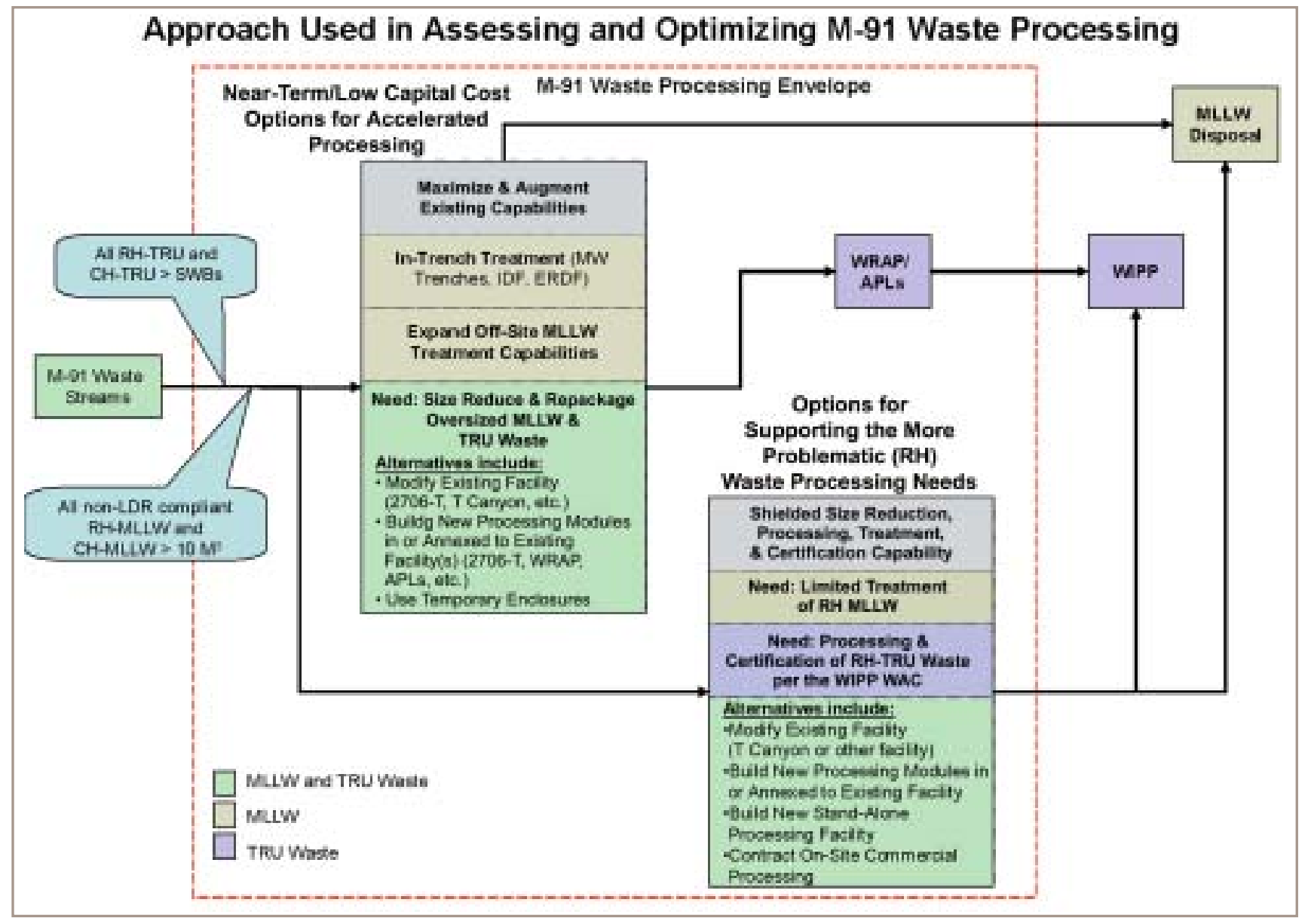

Figure 14. M-91 Processing Evaluation Approach 
Table 2. Alternatives Evaluated

\begin{tabular}{|c|c|c|c|c|c|}
\hline \multicolumn{2}{|c|}{ Alternatives } & \multicolumn{4}{|c|}{ Waste Streams } \\
\hline Primary & Sub-alternatives/ Options & & & TRU & \\
\hline & & Oversized & RH & Oversized & RH \\
\hline In-Trench Treatment of MLLW & NA & $\checkmark$ & $\checkmark$ & & \\
\hline $\begin{array}{l}\text { Expand O ffsite Treatment } \\
\text { Contracts }\end{array}$ & NA & $\checkmark$ & $\checkmark$ & & \\
\hline $\begin{array}{l}\text { CH Repackaging/ Size } \\
\text { Reduction Capability }\end{array}$ & $\begin{array}{l}\text { Modification of Existing } \\
\text { Facility(s) - T Plant Canyon } \\
\text { and 2706-T } \\
\text { Use of New Processing } \\
\text { Modules } \\
\text { Use of Temporary } \\
\text { Containment Enclosures }\end{array}$ & $\checkmark$ & & $\checkmark$ & \\
\hline $\begin{array}{l}\text { RH Processing/ Treatment } \\
\text { Capability }\end{array}$ & $\begin{array}{l}\text { Modification of Existing } \\
\text { Facility - T Plant Canyon } \\
\text { * Modification of Other Existing } \\
\text { Facility(s) - FMEA, MASF, } \\
\text { \& WNP \#1 } \\
\text { Use of New Processing } \\
\text { Modules } \\
\text { * New O nsite Facility - } \\
\text { Line Item } \\
\text { Acquisition of O nsite } \\
\text { Commercial Capability }\end{array}$ & & $\checkmark$ & & $\checkmark$ \\
\hline
\end{tabular}

* Sub-alternatives deemed to be non-viable due to cost and schedule constraints and suitability to the limited processing mission.

The following subsections provide a summary of the alternatives evaluated. O nly those alternatives deemed viable are included in the summary discussion below. Appendix C provides additional details used in the evaluation process, including a brief description of those alternatives deemed to be non-viable. Appendix D provides a listing of the key assumptions that were used in developing the scope and applicability of each alternative to the relevant M-91 processing waste stream(s) and volume(s). These assumptions were developed in conjunction with FH subject matter experts and are useful in establishing a basis for understanding potential processing rates and costs as well as providing a "starting point" for the follow-on engineering evaluations.

\subsection{Augment Existing Capabilities to Accelerate Near-Term Processing}

In order to implement the recommendation to process the more easily managed $\mathrm{CH}$ and low dose RH waste first, several activities have been or will be initiated within the next several years to begin establishing capabilities to treat these waste streams.

In-trench treatment of MLLW is planned for some RH MLLW or oversized $\mathrm{CH}$ containers generated from projects such as suspect TRU retrieval or in some cases, Tank Farm Operations (i.e., some of the LLCE may be too large to be treated by the generator). After applying for and obtaining the required permit modification, treatment to meet the Land D isposal Restriction requirements will be 
performed within the MLLW Disposal Units (LLBG 218-W-5 T31/ T34, IDF, or ERDF) for waste packages containing debris and/ or radioactive lead solids with no treatment path forward. The treatment capability consists of the use of immobilization technologies for mixed waste debris and would be limited to those technologies that can be employed in/ on containerized mixed waste. This capability is anticipated to be operational no later September 30, 2006, and could be accelerated if the permit is approved earlier by the regulators.

Expanded offsite treatment is proposed for MLLW within the package size and dose rate limits of offsite capability. MLLW packages, up to dimensional and dose limits to be determined (although expected to be no greater than $500 \mathrm{mrem} / \mathrm{hr}$ and $10 \mathrm{~m}^{3}$ in size), will be shipped offsite for treatment. Current plans are to obtain limited commercial treatment capability for RH MLLW and MLLW in large containers by September 30, 2004.

Expand/ augment the use of existing facilities to sort and repackage oversized CH MLLW and TRU waste packages. Acquisition of this processing capability is critical in providing treatment for a large volume of the M-91 waste (much of which is either already in storage at CWC or will be retrieved as part of the TRU Retrieval Program). Viable options include:

- Modification of Existing Facilities: O ne of the facilities identified for further evaluation is the 2706-T/ TA building, which could potentially be modified to accept limited quantities of TRU waste packages up to $6 \mathrm{ft} \times 6 \mathrm{ft} \times 10 \mathrm{ft}$ and $\mathrm{RH}$ waste up to one rem/ hr. The 2706-T/ TA building is a certified containment structure for liquids that provides flexibility and that could be upgraded to meet seismic standards, if required. Another such facility is the 221-T Canyon, which has overhead cranes for large packages, shielded cells for storage, and ample room on the canyon deck for processing operations. In addition, both buildings are covered under the T Plant Complex's existing safety basis and permits for handling significant quantities of TRU waste and MLLW.

- Use of new processing modules either within or adjacent to an existing facility (2706-T, 221-T Canyon, WRAP, or mobile TRU processing units).

- Use of temporary containment enclosures either adjacent to or within an existing facility (such as 2706-T, 221-T Canyon, WRAP, or mobile TRU processing units and/ or equipment) to handle large, unique wastes on a case-by-case basis. In addition, such structures could also be used in conjunction with the TRU retrieval operations and/ or the 618-10/ 11 burial ground remediation to allow for limited repackaging operations. The addition of a containment structure directly over the point of excavation reduces the potential release of airborne contamination to the environment. Current commercial mobile structures are available (Figure 15) that have the system capabilities to mitigate the
In-Trench Treatment of MLLW

Scope-For some oversized and RH-MLLW (assume no more than $40 \%$ of the $M-91$ MLLW volume can be processed in-trench)

Cost Implications-Minimal capital costs to set up and low operational costs to implement

Schedule Constraints-Can begin no later than the end of FY06 and potentially sooner

Worker Health \& Safety-Well established ES\&H practices. Operational experience for GTC 3 waste and treatment-by-generator

Regulatory Acceptability-Covered by the HSW EIS and existing safety basis. RCRA Permit Modification would be needed

Benefits/Advantages-Low cost, technically acceptable alternative for some of the larger, more problematic M-91 MLLW

Project Risk/Disadvantages-Applicable only to debris and to $\mathrm{RH}$ waste that can be shielded to $\mathrm{CH}$ levels

\section{Expanded Offsite} Treatment of MLLW

Scope-For some oversized and RH-MLLW (assume no more than $10 \%$ of the M-91 MLLW volume can be sent directly offsite for processing)

Cost Implications-No capital costs to set up, some rate increases likely to deal with the larger and more radioactive waste

Schedule Constraints-Can begin by the end of FY05 and potentially sooner

Worker Health \& Safety-Well established ES\&H practices for offsite contractors. Additional controls may be necessary for packages with elevated dose rates

Regulatory Acceptability-Covered by the HSW EIS, and treatment providers provide safety \& health documentation \& permits

Benefits/Advantages-Low cost, technically acceptable alternative for a small fraction of the M-91 MLLW

Project Risk/Disadvantages-Applicable only to a small fraction of the M-91 MLLW 


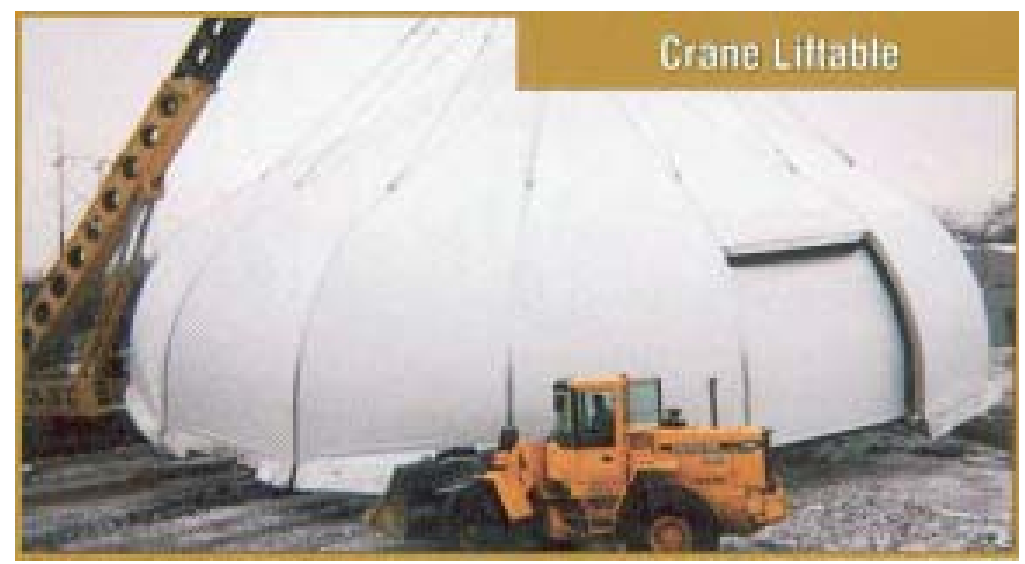

Figure 15. Temporary Containment Structures

limitations identified above. In addition, methodologies have been developed that enable the deployment of such structures with minimal impact on productivity and safety.

It is likely that a combination of facilities and modules will be needed to efficiently and completely meet the M-91 contact-handled oversized waste processing needs. Further analysis of throughput capability and compatibility of the waste processing mission with current work performed in these potential facility(s) will be needed. An Engineering Study (ES) and functional design criteria (FD C) for repackaging, size reduction, visual examination, and treatment of $\mathrm{CH}$ waste too large for current capabilities will be completed by September 30, 2005, followed by potential facility upgrades and/ or acquisition of modules to support the capability in FY06.

\section{Expanded Use of Existing Facilities for MLLW and TRU Waste}

Scope-For remaining oversized CH-MLLW and oversized $\mathrm{CH}$-TRU waste (assume 50\% of the M-91 MLLW volume and $100 \%$ of the M-91 TRU volume will use this processing capability), limited capability for $\mathrm{RH}$ waste

Cost Implications-Low capital costs to implement processing specific needs. However, depending on the facility selected, general facility-wide upgrades may also be required

Schedule Constraints-Engineering study in FY05, upgrades in FY06, with full implementation in $\mathrm{FY} 07$, limited implementation beginning in $\mathrm{FY} 05$

Worker Health \& Safety-Work is an extension of ongoing operations. Some additional protective measures may be needed when dealing with high-levels of transuranic contamination

Regulatory Acceptability-Most options covered by the HSW EIS, existing safety basis, and existing permits

Benefits/Advantages-Low cost, technically acceptable, accelerated alternative for a large fraction of the M-91 MLLW and TRU waste

Project Risk/Disadvantages-T Plant requires $\sim \$ 15 \mathrm{M}$ in upgrades (electrical, water service, and roof) due to aging facility infrastructure

\subsection{Longer-Term RH Waste Processing Capabilities}

Additional RH capability would need to be developed to handle the highest dose MLLW packages and to process and certify the entire RH-TRU waste stream. In order to incorporate design requirements that are driven by the RH WIPP WAC, an ES/ FDC for processing RH-TRU and RH-MLLW will be completed by December 31, 2007. TPA Milestones M-91-05-T01 establishes the deadline for this study. This study will define the capability to treat approximately $7 \%$ of the currently forecasted M-91 waste that is dominated by the entire RH-TRU processing stream. Two primary alternatives are considered viable and worthy of additional evaluation. They include modification of existing facilities with or without new processing modules and the potential acquisition of an onsite commercial capability.

For the Modification of Existing Facilities the viable options include:

- Modification of the 221-T Canyon, which has overhead cranes for large packages, shielded cells for storage, and existing safety basis and environmental permits for handling significant quantities of TRU waste and MLLW was identified as the most attractive existing facility alternative, as previously evaluated in WHC 1995 and WMFS 1998. Other existing facilities, such as the Materials and Storage Facility (MASF), Washington Nuclear Plant 1 Conversion, Fuel \& Materials Examination Facility (FMEF) have been evaluated and rejected in past studies due to permitting issues, costs to upgrade, creation of additional cleanup legacy, and remote locations.

- Use of new processing modules either within or adjacent to an existing facility (2706-T, 221-T Canyon, or mobile TRU processing units). 


\section{Modification of Existing Facilities and Acquisition of New Processing Modules for RH-TRU and RH-MLLW}

Scope-For RH-TRU waste and the remaining $\mathrm{RH}-\mathrm{MLLW}$ (assume $50 \%$ of the M-91 RH-MLLW volume and $100 \%$ of the M-91 RH-TRU volume will use this processing capability), capability to handle oversized packages will also be needed

Cost Implications-Moderate capital and operating costs will be required to implement these processing needs since a robost, shielded and remotely operated module will be required. Depending on the facility selected, general facility-wide upgrades may also be required

Schedule Constraints-Engineering study in FY07, upgrades in FY08 through FY10, with limited implementation beginning in FY12 and potentially sooner

Worker Health \& Safety-Proposed approach must include appropriate ALARA analysis and protective measures to protect workers from high-dose-rate waste.

Shielded modules will likely be necessary

Regulatory Acceptability-Most options covered by the HSW EIS, existing safety basis, and existing permits

Benefits/Advantages-Moderate cost, technically acceptable, accelerated alternative for the remaining fraction of the M-91 MLLW and TRU waste

Project Risk/Disadvantages-T Plant water service, and roof) due to aging infrastructure requires $\sim \$ 15 \mathrm{M}$ in upgrades (electrical,

The design and construction of a new/ permanent processing facility has been evaluated and rejected in past studies due to the high capital costs, lengthy design, construction, and startup schedules, and the creation of an additional cleanup legacy facility that will require $\mathrm{D} \& \mathrm{D}$ once the limited processing mission is completed. The drastic reduction in waste volumes and the goal to accelerate the processing of the waste would only further increase the disadvantages associated with such an alternative.

\section{The acquisition \\ of onsite com- mencial capa- \\ Acquisition of Onsite Commercial Capabilities} bilities is

considered a viable alternative that can be explored with minimal risk in parallel with the development of the engineering studies and FDC for the RH capability upgrades. This option would involve issuing a series of solicitations to determine if there are vendors available willing to finance and locate a remotehandling capability on the

Hanford Site. A similar approach has been used in the past at D OE's Idaho National Engineering and Enviromental Laboratory for $\mathrm{CH}$ waste streams.
Scope-For remaining RH-MLLW and $\mathrm{RH}$ TRU waste (assume $50 \%$ of the M-91 MLLW volume and $100 \%$ of the M-91 TRU volume will use this processing capability), capability to handle large packages will be needed

Cost Implications-No upfront capital costs, operating costs will be based on volume of waste processed

Schedule Constraints-Procurement actions begin in $\mathrm{FY} 06 / 07$, decision to proceed in late $\mathrm{FY} 07$, installation of commercial system onsite in FY08 through FY10, with limited implementation beginning in FY10

Worker Health \& Safety-Proposed approach must include appropriate ALARA analysis and protective measures to protect workers from high dose rate waste. Shielded modules will likely be necessary

Regulatory Acceptability-Would require a supplement to the HSW EIS, as well as establishment of acceptable safety basis documents and permits

Benefits/Advantages-Moderate cost and technically acceptable, while leveraging commercial experience, expertise, and technology (if found to be available)

Project Risk/Disadvantages-Identification of a viable vendor, potential delays in facility installation and regulatory permitting 
The new, phased approach would not only accelerate initiation of the processing of the M-91 waste streams, but would significantly complete the processing mission ahead of the previous baseline and the TPA-mandated processing rates and schedules by nearly a decade.

\subsection{Alternative Evaluation and Conclusions}

The new, phased approach proposed in this evaluation would use a combination of existing and planned processing capabilities to treat the more easily managed $\mathrm{CH}$ waste streams first and would provide for earlier processing of these wastes. This approach would not only accelerate initiation of the processing of the M-91 waste streams, but would significantly complete the processing mission ahead of the previous baseline and the TPA-mandated processing rates and schedules by nearly a decade.

\subsection{Near-Term Actions}

The proposed approach would provide early processing paths for CH MLLW and CH TRU waste in large containers as well as low-dose-rate (less than $1 \mathrm{rem} / \mathrm{hr}$ ) RH MLLW by:

- Expanding assistance to generators to implement Treatment-by-Generator methods for MLLW and assisting the TRU retrieval and burial ground remediation programs to avoid generation of oversized waste containers.

- Procuring limited commercial treatment capability for MLLW. Commercial capability may be able to process up to $500 \mathrm{mrem} / \mathrm{hr}$ and routinely process up to $10 \mathrm{~m}^{3}$ packages, with larger packages handled on a case-by-case basis.

- Initiating Hanford in-trench treatment of MLLW. Long equipment pieces that are categorized as RH MLLW or oversized CH containers from suspect TRU retrieval that are shown to be MLLW may be treated in-trench.

- Leveraging existing capabilities (e.g., modification of the 2706-T/ TA and/ or the 221-T canyon facility) to allow processing of both TRU and MLLW in large packages and limited processing up to one rem/ hr. An engineering study would be conducted in FY05 to define the size reduction and repackaging capabilities needed to accelerate the processing of the oversized CH-MLLW and oversized CH-TRU waste in storage and expected to be generated by the TRU Retrieval Program.

Near-term implementation of some of these waste processing activities could expand existing capabilities by 2005. This accelerated processing approach would

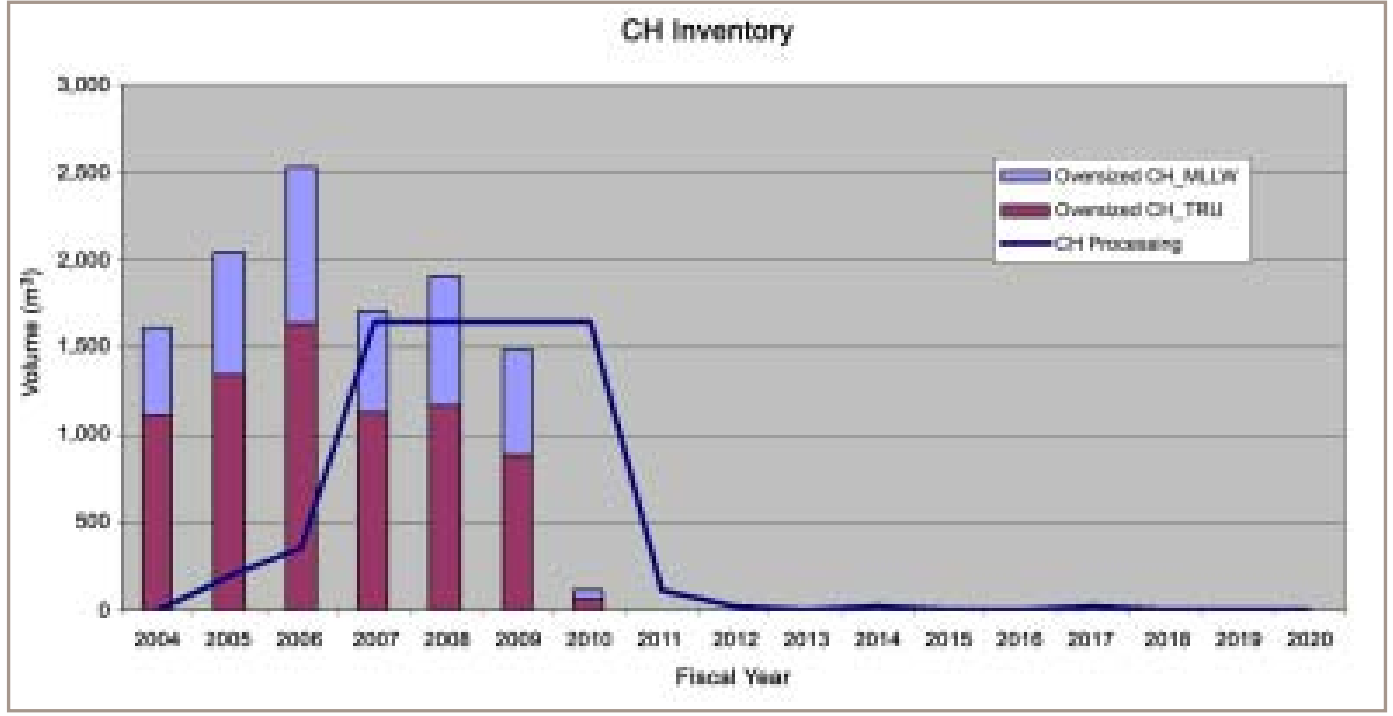

Figure 16. Processing of Oversized $\mathrm{CH}$ Waste support processing of some $\mathrm{CH}$ MLLW and lowactivity RH MLLW a decade earlier than previously planned. Figure 16 provides a conceptual look at the potential "work-off" of the contact-handled waste inventory, including waste in storage, waste forecasted by generators, and waste arising from the TRU Retrieval 
Program. It assumes that a $10 \%$ fraction of the MLLW can be sent directly offsite beginning in FY 05 and $40 \%$ of the MLLW can be treated in-trench beginning in FY06. The remaining oversized CH-MLLW and CH-TRU waste would be processed in the repackaging facility/ module ramping up in FY07. The processing rate for the remaining oversized CH-MLLW and the oversized CH-TRU waste is constrained at 1300 cubic meters per year (which relates to the processing of four $5 \mathrm{ft} \times 5 \mathrm{ft} \times 9 \mathrm{ft}$ boxes per week). This processing rate was developed through discussions with FH T Plant personnel, based on their operation experiences, both in the T Plant canyon and at the 2706-T facility. Use of this processing rate results in the processing mission being complete (or current) near the end of 2010. A small quantity of oversized waste, associated with a single generator (tank farm operations and closure) is projected beyond 2010.

\subsection{Longer-Term Actions for RH Waste}

Additional study is needed for defining and selecting specific capabilities to process high-dose-rate packages, which would leverage from the ongoing experience with the more easily processed waste. The use of either new modules (stand-alone or annexes to existing facilities) or a canyon facility (T Plant) to process the highestdose waste and the largest packages appear to be the most viable alternatives to provide the required treatment capabilities. In addition, the concept of acquiring an onsite commercial treatment capability will also be assessed. A final decision for acquisition of this capability will be determined through an Engineering Study, which is currently scheduled for completion in FY 08 (D ecember 31, 2007). This study is scheduled in FY07 to coincide with the promulgation of final Waste Isolation Pilot Plant Waste Acceptance Criteria for RH TRU waste.

Figure 17 provides a similar "work-off" chart for the RH waste streams. It assumes that a $10 \%$ fraction of the MLLW can be sent directly offsite beginning in FY 05 and $40 \%$ of the MLLW can be treated in trench beginning in FY 06. The remaining RH-MLLW and all the RH-TRU waste would be processed in the $\mathrm{RH}$ facility/ module ramping beginning in FY12. The processing rate for this $\mathrm{RH}$ waste processing capability is constrained at 50 cubic meters per year. This processing rate was developed through discussions with $\mathrm{FH}$ waste management personnel, based on their operation experiences, both at Hanford and at other RH processing facilities within the DOE complex. Based on this approach and processing rate, all $\mathrm{RH}$ waste backlog, including that generated by the 618-10/ 11 burial ground and TRU Retrieval Program, can be processed by

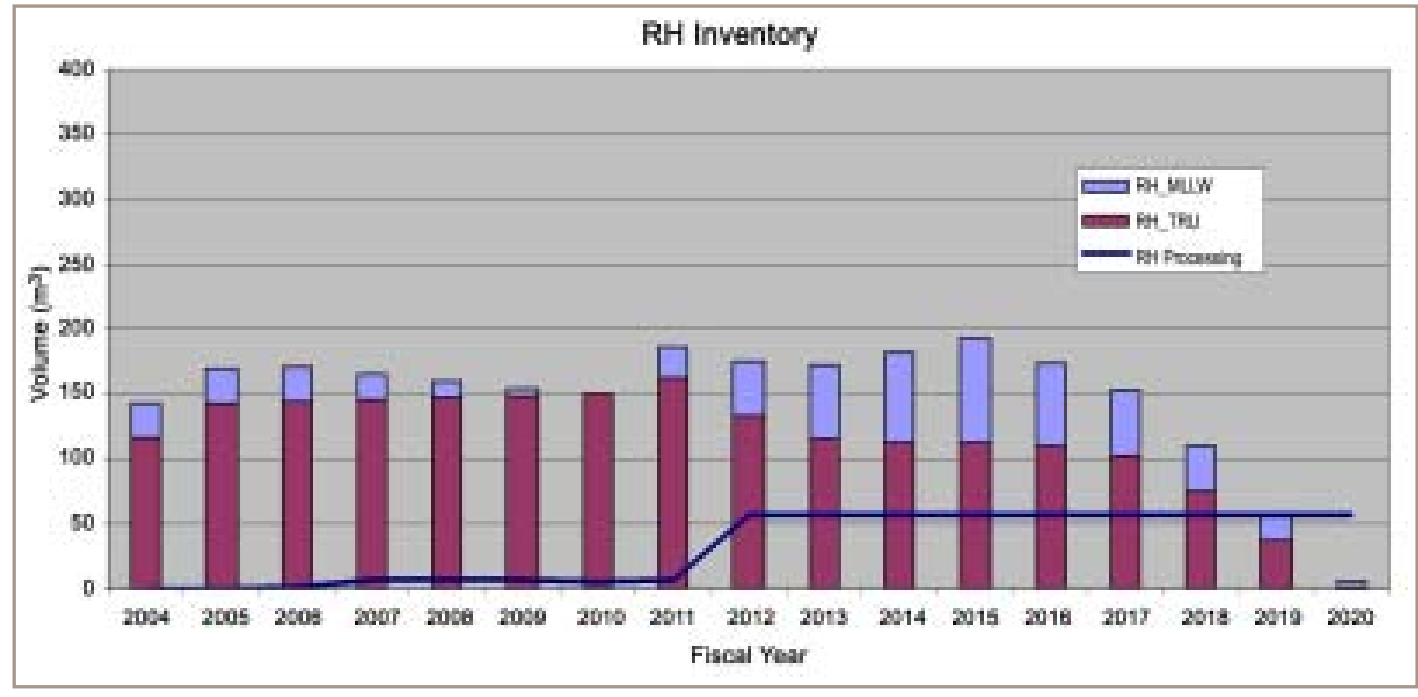

Figure 17. Processing of RH Waste
Additional study is needed for defining and selecting specific capabilities to process high-dose-rate packages. 
Based on this approach and processing rate, all $\mathrm{RH}$ waste backlog, including that generated by the 618-10/11 burial ground and TRU Retrieval Program, can be processed by FY20 (approximately 18 months after completion of these retrieval efforts), significantly in advance of the previous baselines and the TPA Mandated processing rates.
FY20 (approximately 18 months after completion of these retrieval efforts), significantly in advance of the previous baselines and the TPA Mandated processing rates. A small quantity of RH-TRU waste, associated with a single generator (tank farm operations and closure) is projected beyond FY18.

\subsection{Life-Cycle Cost Comparisions}

A high-level cost analysis was performed to determine the potential life-cycle cost savings that could be realized by implementing the new, phased M-91 processing approach proposed in this evaluation. In order to provide a comparable basis for this cost comparison, all costs associated with the construction, upgrade and maintenance of T Plant and/ or other M-91 facilities and the costs of the processing of M-91 waste streams were included.

Appendix D contains the detailed assumptions used in developing the conceptual estimate for the new approach. Appendix E contains the source data tables used in this evaluation. ${ }^{(a)}$ Figures 18 and 19 provide the comparison of life-cycle costs between the existing project planning baseline and the accelerated M-91 processing scenario. As a result of the early retirement of the T Plant facility due to accelerated processing of M-91 waste (including the expanded use of offsite and in-trench treatment), an estimated life-cycle savings of nearly $\$ 125$ million is predicted. In addition, annual costs over the next 4 years were held as close to the existing baseline as possible to ensure that annual funding limitations would not unduly impact this approach. Figure 20 provides the predicted annual savings associated by implementing to new, phased M-91 processing approach.

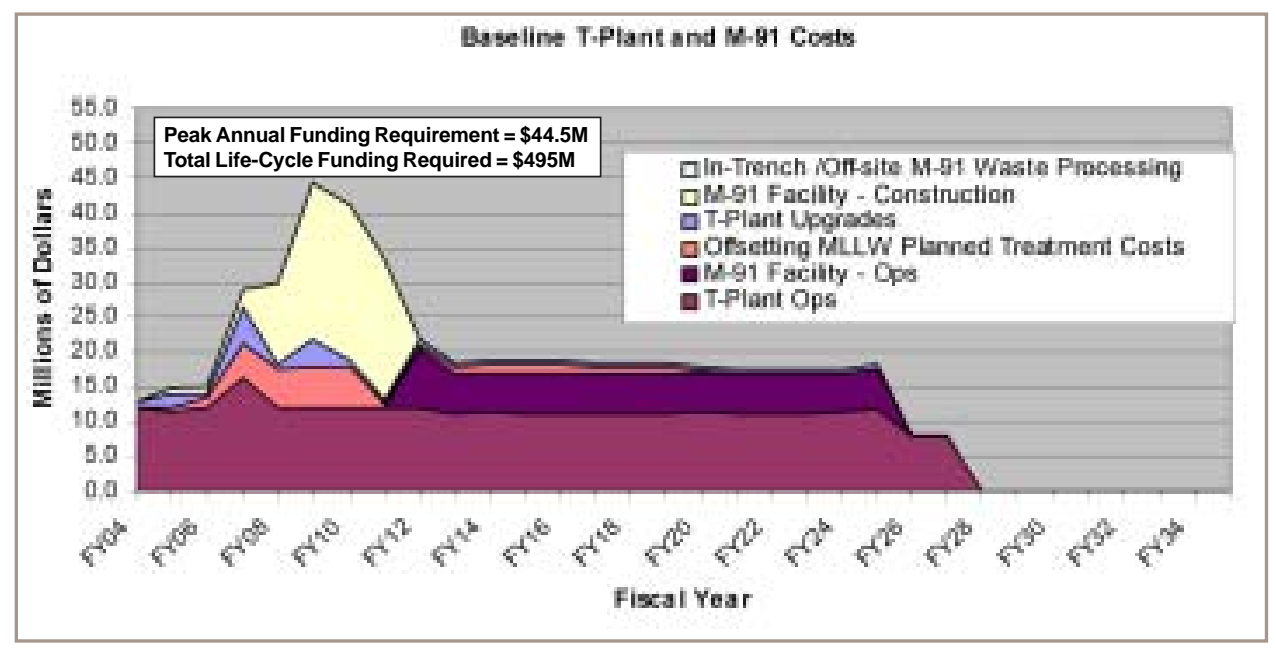

Figure 18. Existing Planning Cost Basis for the M-91 Processing Mission

(a) Source of baseline cost data is the Hanford Life-Cycle Cost Model (D ec 03 FH Baseline + March FY 04 FH WM project planning baseline assumptions provided by FH WM personnel). 
The detailed engineering studies planned for FY 05 and FY 07 will be used to validated and refine the estimates and technical approach pursued. Although the estimates included in this study were derived from existing baseline estimates, they should be considered a high-level, order-of-magnitude analysis of potential costs savings that must be validated through the development of more detailed basis of estimates.

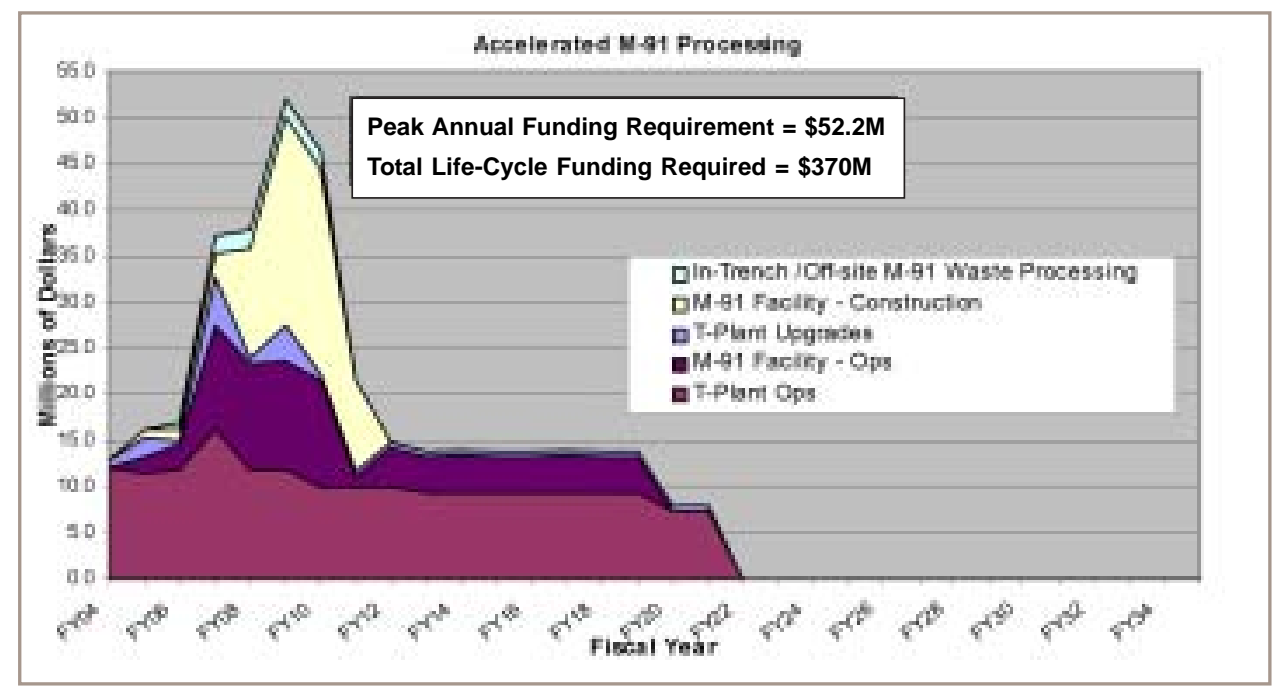

Figure 19. Accelerated Planning Cost Basis for the M-91 Processing Mission

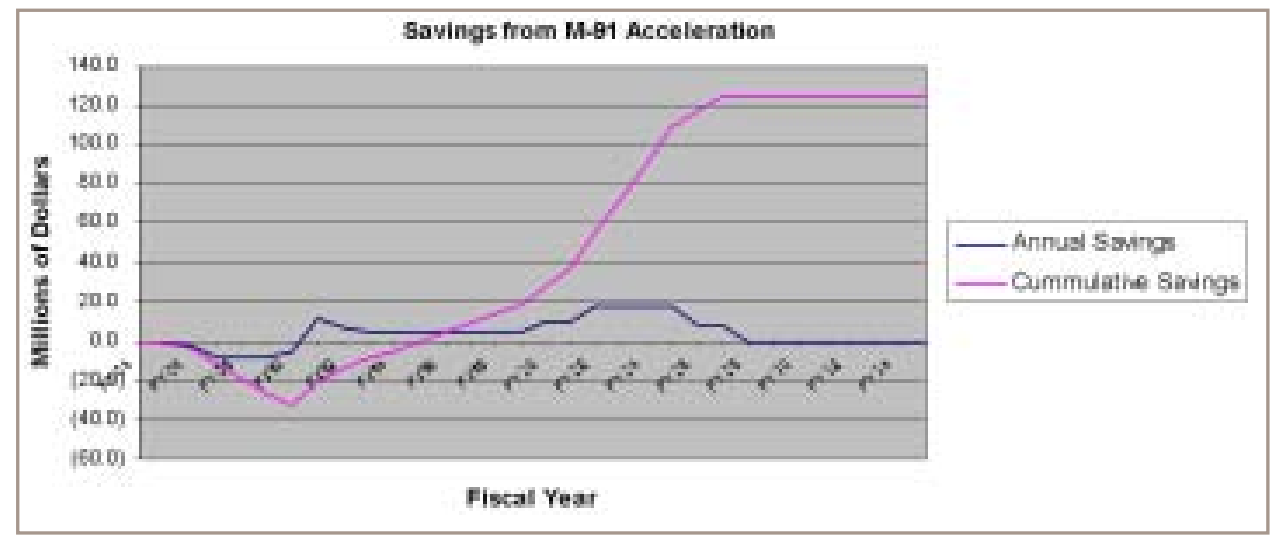

Figure 20. Potential Cost Savings Associated with the M-91 Acceleration Approach 
The following recommendations are made in an effort to accelerate waste processing, maintain a degree of flexibility and redundancy in processing capabilities, and to enable early start and completion of the processing mission.

\subsection{Recommendations and Path Forward}

The following recommendations are made in an effort to accelerate waste processing, maintain a degree of flexibility and redundancy in processing capabilities (to respond to potential future changes in the waste generation, processing requirements, or expected volumes), and enable early start and completion of the processing mission. These recommendations include:

- Continue efforts to reduce the volume of waste that needs processing by an M-91 capability, including supporting Treatment-by-Generator processing and assisting retrieval operations to package waste in standard-size containers if possible. Work with tank farm operations and closure contractor(s) to determine if alternative capabilities can be provided for the waste generated after 2019

- Expand existing commercial MLLW treatment contracts to accept larger and higher-dose-rate packages.

- Work with the regulators on a permit modification to allow in-trench treatment for a fraction of the oversized and RH-MLLW.

- Conduct an engineering study in FY05 to define the size reduction and repackaging capabilities needed to accelerate the processing of the oversized CH-MLLW and oversized CH-TRU waste in storage and expected to be generated by the TRU Retrieval Program and to validate and update the assumptions used in this document. O ptions including modification of existing facilities, use of modules within or adjacent to existing facilities, and use of temporary containment enclosures should be considered. Acquire this capability in FY 06 to allow processing to commence in FY07 resulting in the processing of $\mathrm{CH} \mathrm{M}$ 91 wastes to be complete (or current) by FY11, with small amounts of newly generated oversized $\mathrm{CH}$ wastes to be processed as generated after that.

- Beginning in FY06, initiate the solicitation process (e.g. preparation of procurement documents, scope statements, etc.), through a request for interest, to ascertain the viability of implementing a commercial processing capability for the RH-TRU and remaining RH-MLLW.

- Conduct an engineering study in FY07 (in conjunction with the release of the WIPP RH-TRU WAC) to define the RH waste processing and treatment capabilities needed to complete the M-91 processing mission.

- Based on the solicitation process and the engineering study, a decision point will occur in late FY07 (in conjunction with TPA Milestone M-91-05-T01) to determine the preferred $\mathrm{RH}$ processing approach. This capability will then be acquired (FY08 - FY10), allowing processing to commence in FY12 and potentially sooner.

- Optimize T Plant facility upgrades and operational missions to continue to reduce the volume of backlogged waste, and provide continuity of waste processing missions and expertise.

The M-91 Processing Path Forward Timeline is provided in Figure 21. Current budgets for FY04 through FY32 provide some planned funding for these actions. Some rearrangement of budgets will be needed to implement these recommendations. 


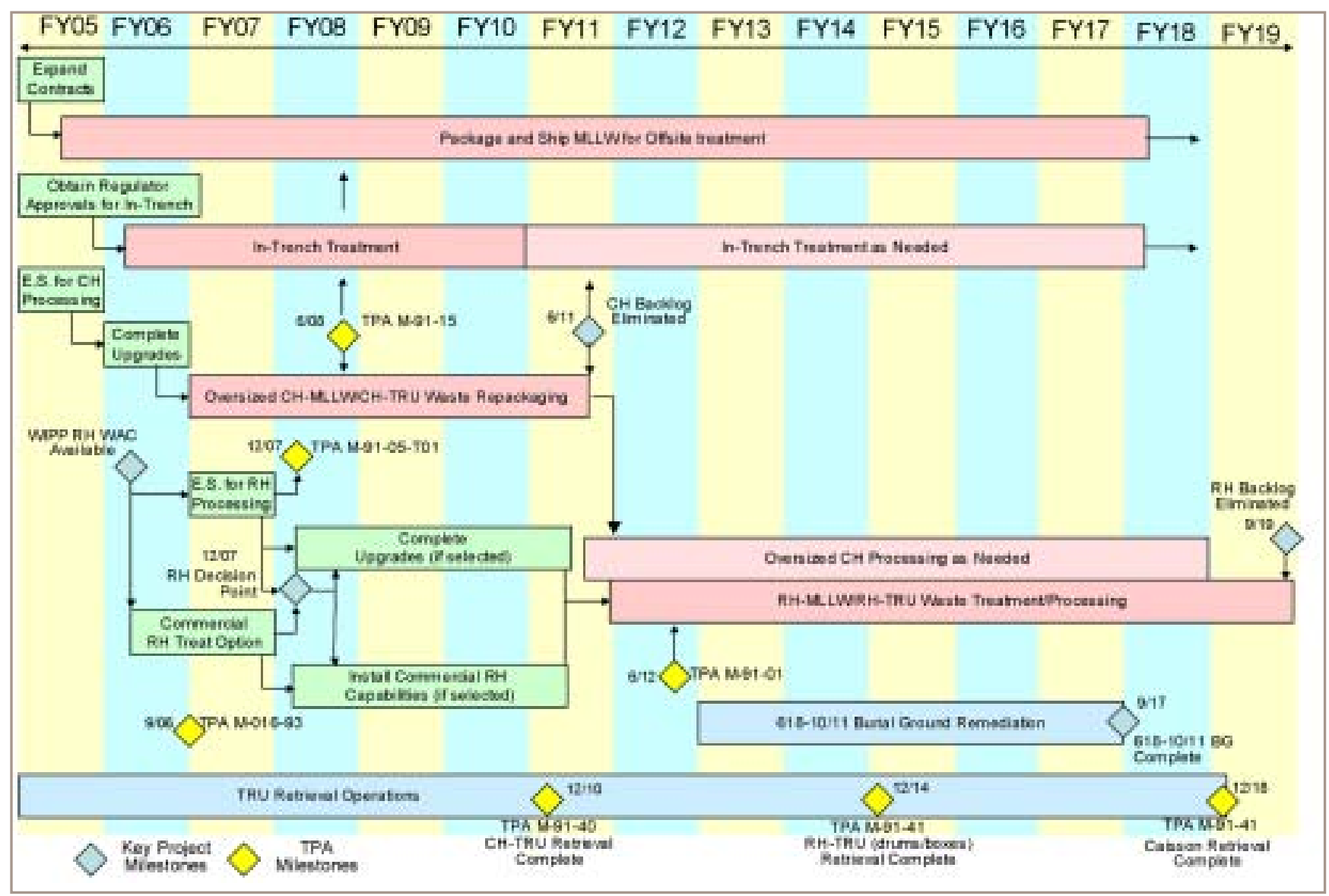

Figure 21. Proposed M-91 Processing Path Forward Timeline 


\subsection{References}

10CFR 61. "Licensing Requirements for Land Disposal of Radioactive Waste." Code of Federal Regulations. O nline at: http:/ / www.access.gpo.gov/ nara/ cfr/ waisidx_02/ 10cfr61_02.html

D OE-RL. 2002. Performance Management Plan for the A coelerated Cleanup of the $H$ anford Site. D OE/ RL-2002-47, Rev. D, U.S. D epartment of Energy, Richland Operations O ffice and the Office of River Protection, Richland, Washington.

D OE. 2004. Final D raft H anford Site Solid (R adioactive and H azardous) W aste Program E nvironmental Impact Statement, Richland Washington. D OE/ EIS-0286F, U.S. D epartment of Energy, Richland Operations Office, Richland, Washington.

Ecology, EPA, and D OE. 2004. H anford Federal Facility A greement and C onsent 0 rder. Change Control Form, Change Number M-16-03-03, Washington State D epartment of Ecology, U.S. Environmental Protection Agency, U.S. D epartment of Energy, Richland, Washington.

Ecology, EPA, and D OE. 1989. H anford Federal Facility A greement and C onsent 0 rder. 89-10 (As Amended). Washington State D epartment of Ecology, U.S. Environmental Protection Agency, U.S. D epartment of Energy, Richland, Washington.

FH. 2004a. Solid Waste Integrated Forecast Technical (SW IFT) Report, FY04-35, 2004.0. HNF-EP-0918, Fluor Hanford Company, Richland, Washington

FH. 2004b. H anford Site Solid Waste A coptance C riteria, HNF-EP-0063, Rev. 10, Fluor Hanford Company, Richland, Washington

WAC 173-303. "Dangerous Waste Regulations." Washington Administrative Code, O lympia, Washington. O nline at: http:/ / www.leg.wa.gov/ wac/ index.cfm?fuseaction $=$ chapterdigest\& chapter $=173-303$

WHC. 1995. Solid Waste and M aterials Systems A lternatives Study. WHC-SD-WMES-341, Rev. 0, Westinghouse Hanford Company, Richland, Washington.

WMFS. 1998. Trade Study for the Processing, Treatment, and Storage of $\mathrm{H}$ anford Site Solid Waste Streams T hat H ave N 0 C urrent Path Forward. HNF-2063, D raft, Waste Management Federal Services of Hanford, Inc., Richland, Washington. 


\subsection{Glossary}

2706-T/ TA - A small exterior building within the T Plant complex that is used for a variety of equipment decontamination and waste packaging and processing operations.

activity - A measure of the quantity of a radioactive material, the special unit of which is the curie and the SI unit is the bequerel.

caisson - Reinforced cylindrical steel and concrete underground structures $2.4 \mathrm{~m}$

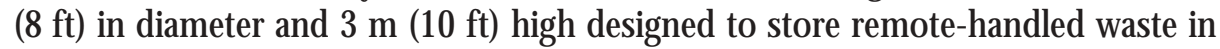
the Low Level Burial Grounds.

cask - A heavily shielded container used to store or ship radioactive materials.

Category 1 low-level waste - Low-level radioactive waste containing radionuclide concentrations within the maximum limits defined for this waste type in the Hanford Site Solid Waste Acceptance Criteria (HSSWAC). These limits are site-specific, and they define the lowest activity category of low-level radioactive waste. Category 1 wastes typically do not require special packaging or treatment for disposal by shallow land burial.

Category 3 low-level waste - Low-level radioactive waste containing radionuclide concentrations greater than those defined for Category 1 waste, but within the maximum limits defined for Category 3 waste in the HSSWAC. These limits are site-specific, and are established using the performance assessment for a particular disposal facility. Category 3 wastes typically require special packaging or treatment for disposal by shallow land burial.

cleanup - The term cleanup refers the full range of projects and activities being undertaken to address environmental and legacy waste issues associated with the Hanford Site.

closure - As applied to radioactive and hazardous waste disposal facilities, the process of site stabilization and placement of caps or other barriers to provide longterm confinement of the waste.

contact-handled (CH) waste - Generally, packaged waste whose external surface dose rate does not exceed $200 \mathrm{mrem} / \mathrm{hr}$ and does not create a high radiation area (>100 mrem/ hr at $30 \mathrm{~cm}$ ). See also remote-handled waste.

dangerous waste - Solid waste designated in WAC 173-303-070 through WAC 173-303-100 as dangerous or extremely hazardous waste, or mixed waste.

deactivation - As applied to waste treatment, the removal of the hazardous characteristics of a waste due to its ignitability, corrosivity, and or reactivity.

decommissioning - Officially remove from service or demolish a facility.

decontamination - Final actions taken to reduce the potential health and safety impacts of DOE-contaminated facilities, including activities to stabilize, reduce, or remove radioactive and hazardous materials. Includes the removal, reduction, or neutralization of radionuclides and/ or hazardous materials from contaminated facilities, equipment, or soils by washing, heating, chemical or electrochemical action, mechanical cleaning, or other techniques. 
disposal - As generally used in this document, placement of waste with no intent to retrieve. Statutory or regulatory definitions of disposal may differ.

dose - The accumulated radiation or hazardous substance delivered to the whole body, or a specified tissue or organ, within a specified time interval, originating from an external or internal source.

generator - Within the context of this document, generators refer to organizations within DOE or managed by DOE whose act or process produces low-level waste, mixed low-level waste, or transuranic waste.

greater than Category 3 (GTC3) low-level waste - Low-level radioactive waste that exceeds the maximum radionuclide concentrations as defined for Category 3 low-level waste. See also Category 3 waste.

\section{H anford Federal Facility Agreement and Consent Order - See Tri-Party} Agreement.

hazardous waste - Waste that contains chemically hazardous constituents regulated under Subtitle $\mathrm{C}$ of the Resource Conservation and Recovery Act (RCRA), as amended (40 CFR 261) and regulated as a hazardous waste and/ or mixed waste by the EPA. May also include solid waste designated by Washington State in WAC 173-303-070 through WAC 173-303-100 as dangerous or extremely hazardous waste, or mixed waste. See also mixed low-level waste.

high-integrity container (H IC) - A container that provides additional confinement for remote-handled Category 3 LLW and some contact-handled Category 3 LLW and is typically constructed of concrete or other durable material.

immobilization - Placing the waste within a material such as concrete or a glass to immobilize (reduce dispersability and leachability of) the radioactive or hazardous components within the waste. See also stabilization.

in-trench grouting - In-trench grouting involves placing the waste on a cement pad or on spacers, installing reinforcement steel and forms around the waste, and covering the waste with fresh concrete to encapsulate the waste within a concrete barrier.

land disposal restrictions - The restrictions and requirements for land disposal of hazardous or dangerous waste as specified in 40 CFR 268 (RCRA) and WAC 173303-140 (Washington State D angerous Waste Regulations).

low-level (radioactive) waste (LLW) - Radioactive waste that is not high-level waste, spent nuclear fuel, transuranic waste, byproduct material (as defined in section 11e[2] of the Atomic Energy Act of 1954, as amended), or naturally occurring radioactive material.

macroencapsulation - Treatment method applicable to debris wastes as defined by RCRA. Refers to application of surface coating materials, such as polymeric organics (for example, resins and plastics) or of a jacket of inert material to reduce surface exposure to potential leaching media. 
mixed low-level waste (MLLW) - Low-level waste determined to contain both source, special nuclear, or byproduct material subject to the Atomic Energy Act of 1954, as amended, and a hazardous component subject to the Resource Conservation and Recovery Act (RCRA), as amended, or Washington State D angerous Waste Regulations. See also hazardous waste, dangerous waste.

non-standard (packaging) - Non-standard waste packages refer to specially designed waste containers or packages used for large, or odd shaped low-level waste, mixed low-level waste or transuranic waste items or items with high dose rates or other unique conditions. See also standard (packaging).

normal operations - As used in this document, normal operations refers to routine waste management activities, for example, waste treatment activities (including processing), packaging and repackaging, storage, and final disposal of waste.

oversized - As used in this report refers to containers of MLLW greater in size than $10 \mathrm{~m}^{3}$ (equivalent to a 6'x6'x10' box) and containers of TRU waste larger than a standard waste box (SWB).

processing - As used in this report, refers to any activity necessary to prepare waste for disposal. Processing waste may consist of repackaging, removal, or stabilization of non-conforming waste, or treatment of physically or chemically hazardous constituents in compliance with state or federal regulations.

radioactive waste - In general, waste that is managed for its radioactive content. Waste material that contains source, special nuclear, or by-product material is subject to regulation as radioactive waste under the Atomic Energy Act.

rem - The special unit of radiation effective dose equivalent (1 rem $=0.01$ Sievert).

remedial action - Activities conducted to reduce potential risks to people and/ or harm to the environment from radioactive and/ or hazardous substance contamination. See also cleanup.

remote-handled (RH) waste - Packaged radioactive waste for which the external dose rate exceeds that defined for contact-handled waste (generally $200 \mathrm{mrem} / \mathrm{hr}$ at the container surface). These wastes require handling using remotely controlled equipment, or placement in shielded containers, to reduce the human exposures during routine waste management activities. See also contact-handled waste.

retrievably stored waste - Waste stored in a manner that is intended to permit retrieval at a future time.

site - A geographic entity comprising leased or owned land, buildings, and other structures required to perform program activities.

stabilization - Mixing an agent such as Portland cement with the waste to increase the mechanical strength of the resulting waste form and decrease its leachability.

standard (packaging) - Standard waste packages refer to the common forms of waste packages (such as drums and boxes) used for low-level waste and mixed low-level waste. See also non-standard (packaging).

storage - The holding of waste for a temporary period, at the end of which the waste is treated, disposed of, or stored elsewhere. 
T Plant Complex - The collection of buildings, environmental permits, and safety basis documentation associated with the entire T Plant facility complex.

T Plant Canyon - The building 221-T, within the T Plant complex, which has shield processing cells, thick shield walls, a processing deck, and installed cranes for moving large items.

Transuranic isotope - Isotopes of any element having an atomic number greater than 92 (the atomic number of uranium).

transuranic (TRU) waste - Transuranic waste is radioactive waste containing more than 100 nanocuries (3700 becquerels) of alpha-emitting transuranic isotopes per gram of waste, with half-lives greater than 20 years, except for the following:

- high-level radioactive waste

- waste that the Secretary of Energy has determined, with the concurrence of the Administrator of the Environmental Protection Agency, does not need the degree of isolation required by the 40 CFR Part 191 disposal regulations

- waste that the Nuclear Regulatory Commission has approved for disposal on a case-by-case basis in accordance with 10 CFR 61.

For the purposes of this document TRU waste may also include hazardous constituents, and may be referred to in the document as mixed TRU waste or TRU (M).

treatment - The physical, chemical, or biological processing of dangerous waste to make such waste non-dangerous or less dangerous, safer for transport, amenable for energy or material resource recovery, amenable for storage, or reduced in volume, with the exception of compacting, repackaging, and sorting as allowed under WAC 173-303-400 and 173-303-600.

Tri-Party Agreement (TPA) - Informal title for the "Hanford Federal Facility Agreement and Consent O rder," an agreement between the U.S. D epartment of Energy, the U.S. Environmental Protection Agency, and the Washington State D epartment of Ecology. The agreement establishes milestones to bring operating DOE facilities into compliance with the RCRA, and to coordinate cleanup of Hanford's inactive disposal sites under the Comprehensive Environmental Response, Compensation, and Liability Act (CERCLA).

waste charactenization - The identification of waste composition and properties, whether by review of process knowledge, or by non-destructive examination, nondestructive assay, or sampling and analysis, to determine appropriate storage, treatment, handling, transportation, and disposal requirements.

waste certification - A process by which a waste generator certifies that a given waste or waste stream meets the waste acceptance criteria of the facility to which the generator intends to transfer waste for treatment, storage, or disposal.

waste container - Any portable device in which a material is stored, transported, treated, disposed, or otherwise handled. A waste container may include any liner or shielding material that is intended to accompany the waste in disposal. At Hanford, waste containers typically consist of 55 gal (208-L) or 85-gal (320-L) drums and standard waste boxes. Other sizes and styles of containers may also be employed depending on the physical, radiological, and chemical characteristics of the waste. 
waste life cycle - The life of a waste from generation through storage, treatment, transportation, and disposal.

waste stream - A waste or group of wastes from a process or a facility with similar physical, chemical, or radiological properties. In the context of this document, a waste stream is defined as a collection of wastes with physical and chemical characteristics that will generally require the same management approach (that is, use of the same storage, treatment, and disposal capabilities). 


\subsection{Acknowledgments}

This evaluation report was prepared in close consultation with a number of key contributors from Fluor Hanford, Inc. (FH) and Pacific Northwest National Laboratory (PNNL). The authors would like to acknowledge the important input and critical reviews provided by these key contributors:

Fluor Hanford, Inc.

Lori Fritz

Ken Hladek

Dave Levinskas

Kent McD onald

Dean Nester

Ken Quigley

Robert Wilkinson
PNNL

Tom D eForest Linda Fassbender

Dave Payson

Paul Scott

Mike Shay

Kelli Templeton

Rose M. Watt

X-West, Inc.

Walt Josephson

Rich Sexton

Joe Swenson 


\section{Appendix A-Current Capabilities of the T Plant Complex}

The T Plant complex has existing air and interim-status dangerous waste permits that provide for relatively high capacities of a wide range of treatment and storage activities. It also has an existing safety basis that supports these activities. This allows the T Plant complex to be used as a "problem-solving" facility for waste streams requiring initial or further characterization, treatment, or repackaging. The facility also provides storage capability, including capacity for wastes with storage challenges such as RH mixed wastes not suitable for storage elsewhere, and high-doserate materials that may need to be placed in a cell for storage. These functions are outlined in Table A.1.

Table A.1. Current Capabilities of T Plant Complex

\begin{tabular}{|c|c|}
\hline Function/ Description & Location/ Alternative \\
\hline $\begin{array}{l}\text { 1. Waste sampling, characterization and treatment of low-dose-rate } \\
\text { LLW and MLLW }\end{array}$ & Primarily 2706-T complex \\
\hline $\begin{array}{l}\text { 2. Waste repackaging/ segregation of low-dose-rate LLW and MW. } \\
\text { D econtamination of large equipment (up to railcar size). }\end{array}$ & Primarily 2706-T complex \\
\hline $\begin{array}{l}\text { 3. Waste sampling and characterization of CH TRU, RH TRU, } \\
\text { high-dose-rate items, and large equipment (up to } 45 \text { tons). }\end{array}$ & 221-T Canyon \\
\hline $\begin{array}{l}\text { 4. Waste Treatment: A variety of waste treatments can be conducted } \\
\text { atT Plant. Treatment covered by the permit includes, but is not } \\
\text { limited to, sorting, segregation, repackaging, neutralization, } \\
\text { absorption, macroencapsulation, and compaction. }\end{array}$ & $\begin{array}{l}\text { 2706-T and 221-T Canyon } \\
\text { (broken down as stated in 1-3 above) }\end{array}$ \\
\hline $\begin{array}{l}\text { 5. Correction of newly generated waste with verification failures or } \\
\text { waste packages that the generators have identified as being } \\
\text { non-compliant with the waste acceptance criteria for the intended } \\
\text { receiving facility. }\end{array}$ & $\begin{array}{l}\text { 2706-T and 221-T Canyon } \\
\text { (broken down as stated in 1-3 above) }\end{array}$ \\
\hline 6. Visual verification of newly generated wastes. & $\begin{array}{l}\text { 2706-T and 221-T Canyon } \\
\text { (broken down as stated in 1-3 above) }\end{array}$ \\
\hline $\begin{array}{l}\text { 7. Mixed and radioactive waste storage. This waste, with the } \\
\text { exception of specific subcategories mentioned elsewhere in this } \\
\text { table, is primarily waste staged for one of the other T-Plant } \\
\text { activities such as characterization or repackaging or awaiting } \\
\text { shipment to disposal or WRAP. }\end{array}$ & $\begin{array}{l}\text { Various locations, including outside pads } \\
\text { within the TSD boundary. }\end{array}$ \\
\hline 8. RH-MLLW/ RH-TRU waste storage & $\begin{array}{l}\text { Primarily canyon cells. Alternatives are limited because } \\
\text { mixed waste must be in permitted TSD s and RH } \\
\text { storage is not allowed in many facilities such as CWC } \\
\text { (unless shielded to CH levels). In addition, many } \\
\text { facilities do not have shielding capabilities to the levels } \\
\text { needed to reduce RH to CH levels. }\end{array}$ \\
\hline $\begin{array}{l}\text { 9. RH non-mixed waste storage, such as RH-TRU waste, that must } \\
\text { be stored pending finalization of the RH WIPP WAC and } \\
\text { processing for shipment to WIPP }\end{array}$ & $\begin{array}{l}\text { Canyon cells or vaults. Currently, storage often } \\
\text { occurs in HICs in the LLBG. }\end{array}$ \\
\hline $\begin{array}{l}\text { 10. K-Basin interim sludge storage. A final decision for interim } \\
\text { storage and treatment of sludge has not been made. Several } \\
\text { scenarios are under consideration, some of which may involve } \\
\text { interim storage of sludge at T Plant }\end{array}$ & $\begin{array}{l}\text { T Plant storage would be in canyon cells. Several } \\
\text { other Site alternatives are being discussed, with } \\
\text { permit requirements presenting a significant barrier } \\
\text { to many of those alternatives. }\end{array}$ \\
\hline 11. Head Space G as Sampling & $\begin{array}{l}\text { 2706-T. This sampling may be conducted with } \\
\text { mobile processing units and at CWC. }\end{array}$ \\
\hline
\end{tabular}




\section{Appendix B-M-91 Waste Volume Forecasts}

Table B.1. Historic Waste Volume Forecasts ${ }^{(a)}$

\begin{tabular}{|c|c|c|c|c|c|c|c|c|}
\hline \multirow[b]{2}{*}{ Forecast } & \multirow[b]{2}{*}{ Cont Size } & \multirow[b]{2}{*}{ Inventory } & \multirow{2}{*}{$\begin{array}{c}\text { Retrievably } \\
\text { Stored }\end{array}$} & \multicolumn{5}{|c|}{ Previous Forecasts } \\
\hline & & & & 2004 & 2003 & 2002 & 2001 & $2000^{1}$ \\
\hline CH-MLLW (Large) & $>10 \mathrm{~m}^{3}$ & 311 & 2,614 & - & 266 & 246 & 3,411 & 653 \\
\hline CH-MLLW (Large LDR-Compliant)2 & $>10 \mathrm{~m}^{3}$ & - & - & 48 & 83 & 2,188 & - & \\
\hline RH-MLLW (Large) & $>10 \mathrm{~m}^{3}$ & - & - & - & - & - & - & 22,947 \\
\hline RH-MLLW (Large LD R-Compliant)2 & $>10 \mathrm{~m}^{3}$ & - & - & 1,577 & 21,769 & 21,769 & 23,451 & \\
\hline RH-MLLW (Non-LDR-Compliant) & & 27 & 153 & 6 & 2,259 & 761 & 2,500 & 7,696 \\
\hline RH-MLLW (LD R-Compliant) ${ }^{2}$ & & - & - & 640 & 4,885 & 5,803 & 5,039 & \\
\hline CH-TRU & $>5 \times 5 \times 9$ & 452 & 5,041 & 199 & 519 & 492 & 880 & 636 \\
\hline CH-TRU & $5 \times 5 \times 9<>$ SWB & 299 & 460 & - & - & - & 12 & - \\
\hline RH-TRU & & 50 & 79 & 270 & 1,698 & 1,296 & 918 & 1,561 \\
\hline M-91 (non-shaded) totals & & 1,138 & 6,347 & 475 & 4,742 & 2,794 & 7,721 & 33,493 \\
\hline
\end{tabular}

(a) Waste volume projections are obtained from the Solid Waste Integrated Forecast Technical (SWIFT) database, with forecast updates from D ecember 2003.

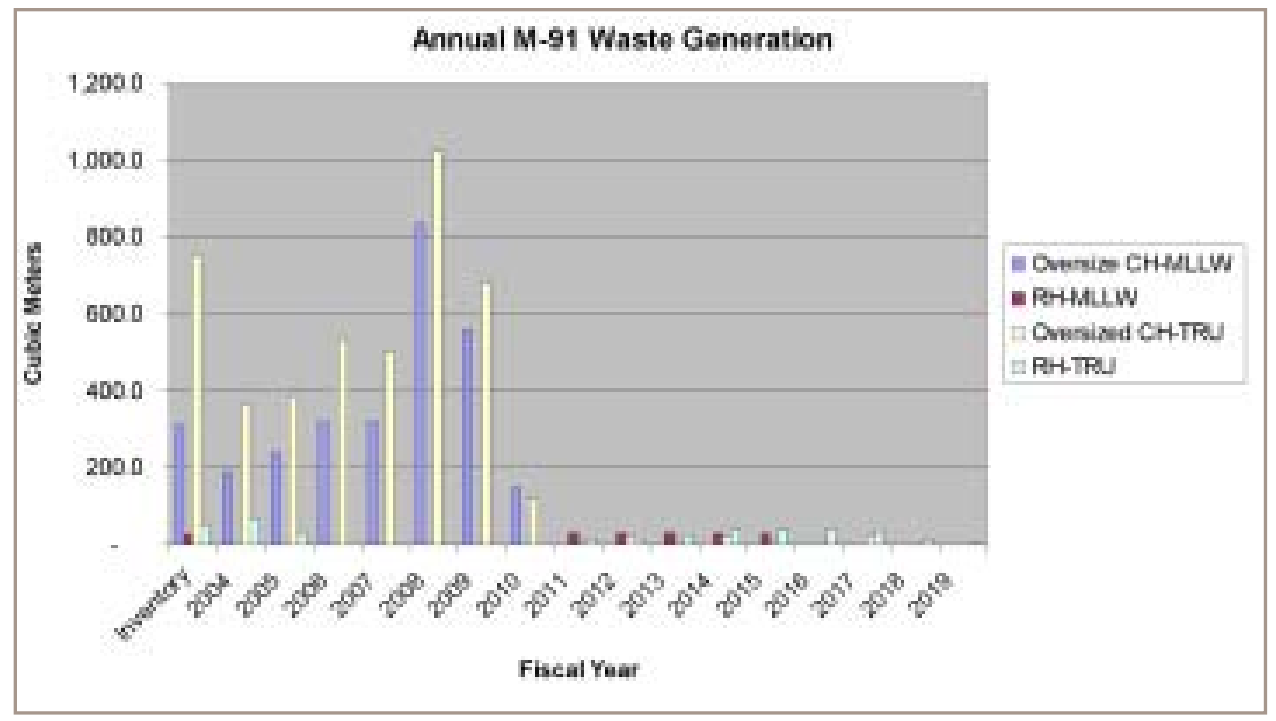

Figure B.1. Annual Waste Generation Projections (Including: Inventory, TRU Retrieval Program, and Forecasts from SWIFT Database) 


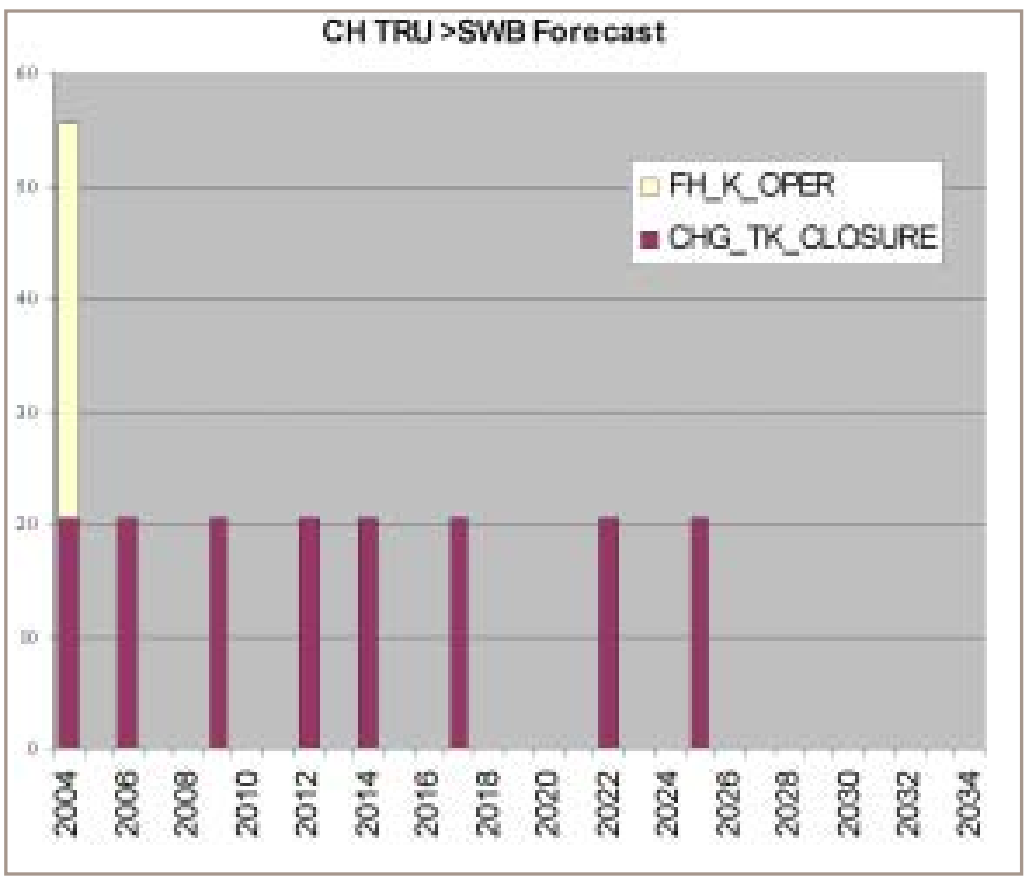

Figure B.2 Oversized Contact-Handled TRU Waste Forecasts from SWIFT Database

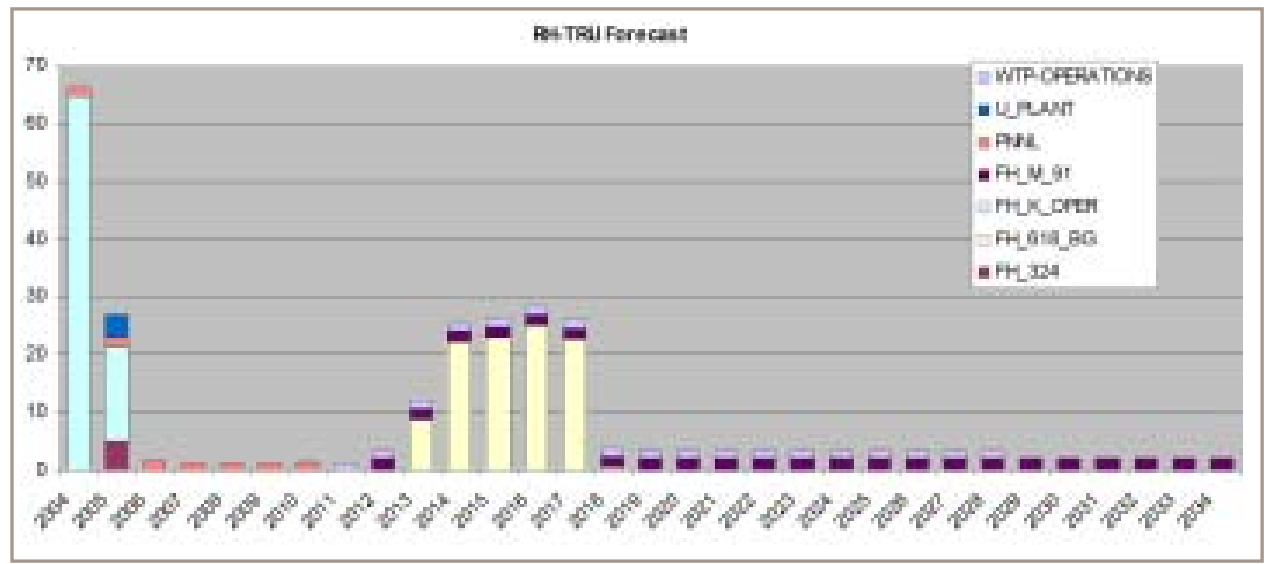

Figure B.3 Remote-Handled TRU Waste Forecasts from SWIFT Database 


\section{Appendix C-Evaluation of Alternatives}

Table C.1. Qualitative Evaluation of Alternatives

\begin{tabular}{|c|c|c|c|c|c|c|c|c|}
\hline Altemative & $\begin{array}{l}\text { Description/ } \\
\text { Scope }\end{array}$ & $\begin{array}{c}\text { Waste } \\
\text { Streams }\end{array}$ & $\begin{array}{c}\text { Cost } \\
\text { Implications }\end{array}$ & $\begin{array}{l}\text { Schedule } \\
\text { Constraints }\end{array}$ & $\begin{array}{c}\text { Worker Health } \\
\text { \& Safety }\end{array}$ & $\begin{array}{c}\text { Regulatory } \\
\text { Acceptability }\end{array}$ & Benefits & Risk \\
\hline \multicolumn{9}{|c|}{ Near-term MLLW Treatment Options Using Existing Capabilities ${ }^{(a)}$} \\
\hline In-Trench & $\begin{array}{l}\text { In-trench } \\
\text { Macro- } \\
\text { encapsulation } \\
\text { of waste }\end{array}$ & $\begin{array}{l}\text { Some RH- } \\
\text { MLLW and } \\
\text { oversized } \\
\text { CH-MLLW }\end{array}$ & $\begin{array}{l}\text { This option is very } \\
\text { attractive from a } \\
\text { cost viewpoint. } \\
\text { Direct costs are } \\
\text { assumed to be } \\
\$ 4 \mathrm{k}-\$ 7 \mathrm{k} / \mathrm{m}^{3} \text {. } \\
\text { Facility permit- } \\
\text { ting, upgrade, } \\
\text { maintenance, and } \\
\text { D \&D costs are } \\
\text { largely avoided. }\end{array}$ & $\begin{array}{l}\text { Can be } \\
\text { implemented } \\
\text { as soon as } \\
\text { permitting } \\
\text { documentation } \\
\text { can be put in } \\
\text { place. No facility } \\
\text { modification or } \\
\text { upgrade delays. }\end{array}$ & $\begin{array}{l}\text { This option will } \\
\text { require special } \\
\text { considerations } \\
\text { when implementing } \\
\text { to ensure workers } \\
\text { and the environment } \\
\text { are sufficiently } \\
\text { protected. However, } \\
\text { experience gained in } \\
\text { treating GTC } 3 \text { waste } \\
\text { and treatment-by- } \\
\text { generator can be } \\
\text { used in establishing } \\
\text { ES\&H requirements. }\end{array}$ & $\begin{array}{l}\text { This is an area } \\
\text { where this option } \\
\text { has some vulnerability. } \\
\text { Ecology has been } \\
\text { reluctant to grant the } \\
\text { wide-scale use of in- } \\
\text { trench treatment in the } \\
\text { past. This reluctance } \\
\text { will need to be overcome } \\
\text { and a modification to } \\
\text { the RCRA Site permit } \\
\text { will be required. This } \\
\text { approach is covered } \\
\text { by the HSW EIS. }\end{array}$ & $\begin{array}{l}\text { Clear cost and } \\
\text { schedule acceleration } \\
\text { advantages with } \\
\text { proven technologies } \\
\text { and approaches. }\end{array}$ & $\begin{array}{l}\text { Applicable only to } \\
\text { debris MLLW and to } \\
\mathrm{RH} \text { wastes that can } \\
\text { be shielded to } \mathrm{CH} \\
\text { levels. Must be able } \\
\text { to convince Ecology } \\
\text { of the benefits of } \\
\text { this approach to } \\
\text { allow it to proceed } \\
\text { further. }\end{array}$ \\
\hline $\begin{array}{l}\text { Offsite } \\
\text { Contracts }\end{array}$ & $\begin{array}{l}\text { Expand use of } \\
\text { contracts to } \\
\text { handle higher } \\
\text { dose and larger } \\
\text { packages }\end{array}$ & $\begin{array}{l}\text { Limited RH- } \\
\text { MLLW and } \\
\text { oversized } \\
\text { CH-MLLW }\end{array}$ & $\begin{array}{l}\text { This option is very } \\
\text { attractive from a } \\
\text { cost viewpoint, if } \\
\text { the incremental } \\
\text { costs to handle } \\
\text { oversized or higher } \\
\text { dose rate items } \\
\text { are not excessive. } \\
\text { No capital costs } \\
\text { are needed. }\end{array}$ & \begin{tabular}{l|} 
Can be \\
implemented \\
nearly immediately. \\
Assumes processing \\
can begin in \\
FY 05.
\end{tabular} & $\begin{array}{l}\text { Health \& Safety } \\
\text { standards and practices } \\
\text { for the commercial } \\
\text { vendors are well } \\
\text { established. Some } \\
\text { additional controls may } \\
\text { be necessary as both } \\
\text { size and dose rates of } \\
\text { packages are increased. }\end{array}$ & $\begin{array}{l}\text { Contractors provide the } \\
\text { health \& safety standards } \\
\text { and regulatory permits } \\
\text { for the treatment. } \\
\text { Changes may require } \\
\text { vendors to update their } \\
\text { permits. This approach } \\
\text { is covered by the HSW } \\
\text { EIS. }\end{array}$ & $\begin{array}{l}\text { Low capital cost, } \\
\text { technically proven } \\
\text { alternative for a small } \\
\text { fraction of the M-91 } \\
\text { waste stream. }\end{array}$ & $\begin{array}{l}\text { Only applicable to a } \\
\text { small fraction of the } \\
\text { M-91 waste stream. } \\
\text { Cost premiums are } \\
\text { likely to be charged } \\
\text { for the higher dose } \\
\text { rate and oversized } \\
\text { packages. }\end{array}$ \\
\hline \multicolumn{9}{|c|}{ Other Near-term Options for CH Repackaging/ Size Reduction Capability ${ }^{(b)}$} \\
\hline $\begin{array}{l}\text { Modifi- } \\
\text { cation of } \\
\text { Facilities }\end{array}$ & $\begin{array}{l}\text { Modification } \\
\text { of Existing } \\
\text { Facility(s) - } \\
\text { T Plant } \\
\text { Canyon and } \\
2706-T\end{array}$ & $\begin{array}{l}\text { Oversized } \\
\text { CH-MLLW } \\
\text { and CH-TRU } \\
\text { waste }\end{array}$ & $\begin{array}{l}\text { Low capital costs } \\
\text { needed to implement } \\
\text { processing related } \\
\text { upgrades/ modules. } \\
\text { (<\$1M) Containment } \\
\text { tents within T Plant } \\
\text { canyon (for the } \\
\text { oversized CH TRU } \\
\text { waste) and within } \\
\text { 2706-T (for the over- } \\
\text { sized CH MLLW) } \\
\text { have modest minimal } \\
\text { capital costs. Operat- } \\
\text { ing costs are well } \\
\text { understood and this } \\
\text { approach is largely } \\
\text { an extension of } \\
\text { existing practices. }\end{array}$ & $\begin{array}{l}\text { An engineering } \\
\text { study would need to } \\
\text { be performed in } \\
\text { FY } 05 \text { to finalize the } \\
\text { design requirements, } \\
\text { approach, and } \\
\text { location of the } \\
\text { capabilities. If the } \\
\text { T Plant alternative } \\
\text { is not selected, } \\
\text { delays in permitting } \\
\text { and safety basis } \\
\text { planning could } \\
\text { result. }\end{array}$ & $\begin{array}{l}\text { In general, this work } \\
\text { would be an extension } \\
\text { of existing practices. } \\
\text { In cases of high levels } \\
\text { of TRU contamination, } \\
\text { additional protective } \\
\text { measures would be } \\
\text { needed (e.g., engineered } \\
\text { barriers, ventilation, } \\
\text { personnel protective } \\
\text { equipment). }\end{array}$ & $\begin{array}{l}\text { Most probable options } \\
\text { covered by the HSW } \\
\text { EIS, existing safety basis, } \\
\text { and existing environ- } \\
\text { mental permits. }\end{array}$ & $\begin{array}{l}\text { Low cost, technically } \\
\text { acceptable, } \\
\text { accelerated alternative } \\
\text { for a large fraction of } \\
\text { the M-91 MLLW and } \\
\text { TRU waste currently } \\
\text { in inventory or to be } \\
\text { generated over the } \\
\text { next } 5 \text { years. Material } \\
\text { handling capabilities } \\
\text { exist at T Plant. }\end{array}$ & $\begin{array}{l}\text { T Plant requires } \\
\sim \$ 15 \mathrm{M} \text { in plant-wide } \\
\text { upgrades (electrical, } \\
\text { water service, and } \\
\text { roof) due to aging } \\
\text { facility infra- } \\
\text { structure. }\end{array}$ \\
\hline $\begin{array}{l}\text { New } \\
\text { Processing } \\
\text { Modules }\end{array}$ & $\begin{array}{l}\text { Use of New } \\
\text { Processing } \\
\text { Modules }\end{array}$ & $\begin{array}{l}\text { Oversized } \\
\text { CH-MLLW } \\
\text { and CH-TRU } \\
\text { Waste }\end{array}$ & \begin{tabular}{|l|} 
Standalone modules \\
will likely have a \\
slightly higher capital \\
cost than modules/ \\
upgrades within an \\
existing facility. \\
Start-up and \\
permitting costs \\
would need to be \\
included as well.
\end{tabular} & $\begin{array}{l}\text { Standalone modules } \\
\text { may take longer to } \\
\text { procure and startup } \\
\text { than facility modi- } \\
\text { fications, thus } \\
\text { further delaying } \\
\text { processing. }\end{array}$ & $\begin{array}{l}\text { In general, this work } \\
\text { would be an extension } \\
\text { of existing practices. } \\
\text { In cases of high levels } \\
\text { of TRU contamination, } \\
\text { additional protective } \\
\text { measures would be } \\
\text { needed (e.g., engineered } \\
\text { barriers, ventilation, } \\
\text { personnel } \\
\text { protective equipment). }\end{array}$ & $\begin{array}{l}\text { Most probable options } \\
\text { covered by the HSW EIS } \\
\text { (such as the use of } \\
\text { APLs). Development } \\
\text { of safety basis and } \\
\text { environmental permits } \\
\text { may be needed. }\end{array}$ & $\begin{array}{l}\text { Low cost, technically } \\
\text { acceptable, } \\
\text { accelerated alternative. } \\
\text { Avoids heavy } \\
\text { mortgage costs } \\
\text { associated with } \\
\text { existing/ aging } \\
\text { facilities. Could be } \\
\text { collocated with an } \\
\text { existing facility } \\
\text { (2706-T, WRAP, etc.) } \\
\text { to streamline } \\
\text { processing options. }\end{array}$ & $\begin{array}{l}\text { Schedule delays are } \\
\text { possible with the } \\
\text { standalone module } \\
\text { approach and would } \\
\text { require additional } \\
\text { management } \\
\text { attention. }\end{array}$ \\
\hline $\begin{array}{l}\text { Temporary } \\
\text { Enclosures }\end{array}$ & $\begin{array}{l}\text { Use of } \\
\text { Temporary } \\
\text { Containment } \\
\text { Enclosures in } \\
\text { conjunction } \\
\text { with retrieval/ } \\
\text { remedial } \\
\text { operations. }\end{array}$ & $\begin{array}{l}\text { Oversized } \\
\text { CH-MLLW } \\
\text { and CH-TRU } \\
\text { waste }\end{array}$ & $\begin{array}{l}\text { Costs are generally } \\
\text { low, on the order of } \\
\$ 10 \text { 'sk to low } \$ 100 \text { 'sk }\end{array}$ & $\begin{array}{l}\text { May impact retrieval } \\
\text { schedules and plans } \\
\text { if repackaging } \\
\text { operations are } \\
\text { performed in the } \\
\text { field. }\end{array}$ & $\begin{array}{l}\text { Potential health and } \\
\text { Safety concerns } \\
\text { requiring enhanced } \\
\text { controls in the field. } \\
\text { Hazards would be } \\
\text { exacerbated by opening } \\
\text { intact containers. }\end{array}$ & $\begin{array}{l}\text { Would require safety and } \\
\text { environmental reviews } \\
\text { prior to implementing. }\end{array}$ & $\begin{array}{l}\text { Viable option for } \\
\text { repacking damaged } \\
\text { oversized containers } \\
\text { into standard waste } \\
\text { packages. }\end{array}$ & $\begin{array}{l}\text { Limited applicability. } \\
\text { Possible worker } \\
\text { health \& safety } \\
\text { concerns. Possible } \\
\text { coordination } \\
\text { concerns with the } \\
\text { retrieval/ remedial } \\
\text { operations. }\end{array}$ \\
\hline
\end{tabular}

(a) These options expand the use of existing capabilities for higher dose rate and larger MLLW packages.

(b) Use or modification of other onsite processing facilities or construction of a new facility were not considered possible alternatives for the near-term accelerated $\mathrm{CH}$ processing capability due to the extended time needed to design, construct, permit, and start up such a capability. 
Table C.1. Qualitative Evaluation of Alternatives (contd)

\begin{tabular}{|c|c|c|c|c|c|c|c|c|}
\hline Altemative & $\begin{array}{l}\text { Description/ } \\
\text { Scope }\end{array}$ & $\begin{array}{c}\text { Waste } \\
\text { Streams }\end{array}$ & $\begin{array}{c}\text { Cost } \\
\text { Implications }\end{array}$ & $\begin{array}{l}\text { Schedule } \\
\text { Constraints }\end{array}$ & $\begin{array}{c}\text { Worker Health } \\
\text { \& Safety }\end{array}$ & $\begin{array}{c}\text { Regulatory } \\
\text { Acceptability }\end{array}$ & Benefits & Risk \\
\hline \multicolumn{9}{|c|}{ RH Processing/ Treatment Capability ${ }^{(\mathrm{c})}$} \\
\hline $\begin{array}{l}\text { Modifica- } \\
\text { tion of } \\
\text { T Plant } \\
\text { Canyon }\end{array}$ & $\begin{array}{l}\text { Modification } \\
\text { of Existing } \\
\text { Facility - } \\
\text { T Plant } \\
\text { Canyon }\end{array}$ & $\begin{array}{l}\text { Remaining } \\
\text { RH-MLLW } \\
\text { and RH-TRU } \\
\text { waste }\end{array}$ & $\begin{array}{l}\text { Moderate capital } \\
\text { costs ( } \$ 50 \mathrm{M} \text { to } \\
\$ 100 \mathrm{M} \text { range) }\end{array}$ & $\begin{array}{l}\text { An Engineering } \\
\text { Study (ES) would } \\
\text { need to be perform- } \\
\text { ed in FY07 allowing } \\
\text { upgrades to be made } \\
\text { in FY08 - FY } 10 . \\
\text { T Plant wide } \\
\text { upgrades can be } \\
\text { implemented earlier. }\end{array}$ & $\begin{array}{l}\text { RH Modules within the } \\
\text { T Plant canyon are } \\
\text { compatible with past } \\
\text { and ongoing operations. } \\
\text { High dose rates and } \\
\text { contamination levels } \\
\text { will require additional } \\
\text { protective measures } \\
\text { (e.g., engineered } \\
\text { barriers/ shielding, } \\
\text { remote operations, } \\
\text { ventilation, personnel } \\
\text { protective equipment). }\end{array}$ & $\begin{array}{l}\text { T Plant is currently } \\
\text { permitted to handle } \\
\text { wastes of these types. } \\
\text { D NFSB issues, associated } \\
\text { with the aging T Plant } \\
\text { facility, would have to be } \\
\text { addressed. Covered by } \\
\text { the HSW EIS preferred } \\
\text { alternative. }\end{array}$ & $\begin{array}{l}\text { Moderate costs, } \\
\text { technical acceptable, } \\
\text { accelerated alternative } \\
\text { for the remaining } \\
\text { fraction of M-91 } \\
\text { MLLW and TRU } \\
\text { waste requiring } \\
\text { processing. }\end{array}$ & $\begin{array}{l}\mathrm{T} \text { Plant complex } \\
\text { wide upgrades are } \\
\text { an additional cost. }\end{array}$ \\
\hline $\begin{array}{l}\text { Modifica- } \\
\text { tion of } \\
\text { other } \\
\text { Existing } \\
\text { Hanford } \\
\text { Facility }\end{array}$ & $\begin{array}{l}\text { Modification } \\
\text { of other Exist } \\
\text {-ing Facility(s)- } \\
\text { FMEF, MASF, } \\
\text { \& WNP \#1 }\end{array}$ & $\begin{array}{l}\text { Remaining } \\
\text { RH-MLLW } \\
\text { and RH-TRU } \\
\text { waste }\end{array}$ & $\begin{array}{l}\text { Moderate capital } \\
\text { costs ( } \$ 50 \mathrm{M} \text { to } \\
\$ 100 \mathrm{M} \text { range) for } \\
\text { processing modifica- } \\
\text { tions could } \\
\text { introduce new } \\
\mathrm{D} \& \mathrm{D} \text { costs. }\end{array}$ & $\begin{array}{l}\text { An ES would need } \\
\text { to be performed in } \\
\text { FY07 allowing } \\
\text { upgrades to be made } \\
\text { in FY08 - FY10. }\end{array}$ & $\begin{array}{l}\text { RH modules within } \\
\text { other existing facilities } \\
\text { may not be compatible } \\
\text { with their past } \\
\text { operations. High dose } \\
\text { rates and contamination } \\
\text { levels will require } \\
\text { additional protective } \\
\text { measures (e.g., } \\
\text { engineered barriers/ } \\
\text { shielding, remote } \\
\text { operations, ventilation, } \\
\text { personnel protective } \\
\text { equipment). }\end{array}$ & $\begin{array}{l}\text { It would be very } \\
\text { difficult, both in terms } \\
\text { of time and cost in } \\
\text { obtaining regulatory } \\
\text { permits for an existing } \\
\text { facility that was not built } \\
\text { for such a mission. A } \\
\text { supplement to the HSW } \\
\text { EIS would likely be } \\
\text { needed. }\end{array}$ & $\begin{array}{l}\text { Because some of the } \\
\text { other facilities } \\
\text { considered are } \\
\text { currently unconta- } \\
\text { minated, installation } \\
\text { and upgrade costs for } \\
\text { new modules would } \\
\text { likely be less than for } \\
\text { T Plant. }\end{array}$ & $\begin{array}{l}\text { As documented in } \\
\text { previous M-91 } \\
\text { evaluations, this } \\
\text { option is not } \\
\text { deemed a viable } \\
\text { alternative due to } \\
\text { the cost and time } \\
\text { needed to imple- } \\
\text { ment, location } \\
\text { disadvantages, and } \\
\text { creation of new } \\
\text { legacy cleanup } \\
\text { costs. }\end{array}$ \\
\hline $\begin{array}{l}\text { New } \\
\text { Processing } \\
\text { Modules }\end{array}$ & $\begin{array}{l}\text { Use of New } \\
\text { Processing } \\
\text { Modules within } \\
\text { or adjacent to } \\
\text { an existing } \\
\text { facility }\end{array}$ & $\begin{array}{l}\text { Remaining } \\
\text { RH-MLLW } \\
\text { and RH-TRU } \\
\text { waste }\end{array}$ & $\begin{array}{l}\text { Moderate capital } \\
\text { costs ( } \$ 50 \mathrm{M} \text { to } \\
\$ 100 \mathrm{M} \text { range), along } \\
\text { with permitting and } \\
\text { startup costs. }\end{array}$ & $\begin{array}{l}\text { An ES would need } \\
\text { to be performed } \\
\text { in FY } 07 \text { allowing } \\
\text { upgrades to be made } \\
\text { in FY08 - FY10. }\end{array}$ & $\begin{array}{l}\text { RH modules dealing } \\
\text { with high dose rates and } \\
\text { contamination levels will } \\
\text { require additional } \\
\text { protective measures } \\
\text { (e.g., engineered } \\
\text { barriers/ shielding, } \\
\text { remote operations, } \\
\text { ventilation, personnel } \\
\text { protective equipment). }\end{array}$ & $\begin{array}{l}\text { A standalone module } \\
\text { would need to undergo } \\
\text { new permitting and } \\
\text { safety basis documenta- } \\
\text { tion. However, a module } \\
\text { located either within or } \\
\text { adjacent to an existing } \\
\text { facility would only } \\
\text { require updates to such } \\
\text { documentation. A } \\
\text { supplement to the HSW } \\
\text { EIS could be needed. }\end{array}$ & $\begin{array}{l}\text { Moderate costs, } \\
\text { technically acceptable, } \\
\text { accelerated alternative } \\
\text { for the remaining } \\
\text { fraction of M-91 } \\
\text { MLLW and TRU } \\
\text { waste requiring } \\
\text { processing. }\end{array}$ & $\begin{array}{l}\text { If pursued as a } \\
\text { standalone option } \\
\text { permitting and } \\
\text { start-up actions } \\
\text { could impact } \\
\text { implementation. }\end{array}$ \\
\hline $\begin{array}{l}\text { New } \\
\text { Processing } \\
\text { Facility }\end{array}$ & $\begin{array}{l}\text { New Onsite } \\
\text { Facility - Line } \\
\text { Item }\end{array}$ & $\begin{array}{l}\text { Remaining } \\
\text { RH-MLLW } \\
\text { and RH-TRU } \\
\text { waste }\end{array}$ & $\begin{array}{l}\text { High capital and } \\
\text { startup costs }(\$ 350 \mathrm{M} \\
+ \text { range) }\end{array}$ & $\begin{array}{l}\text { An ES would need } \\
\text { to be performed in } \\
\text { FY07 allowing design } \\
\text { and funding deci- } \\
\text { sions to proceed. } \\
\text { D esign and con- } \\
\text { struction would } \\
\text { occur over the next } \\
5 \text { years with startup } \\
\text { not possible until } \\
2012 \text { at the earliest. }\end{array}$ & $\begin{array}{l}\text { A new facility would be } \\
\text { designed and con- } \\
\text { structed to protect } \\
\text { workers and the } \\
\text { environment from the } \\
\text { hazards associated with } \\
\text { these waste streams. }\end{array}$ & $\begin{array}{l}\text { A new facility would } \\
\text { require a complete set of } \\
\text { safety basis and environ- } \\
\text { mental permits. A } \\
\text { supplement to the HSW } \\
\text { EIS would be required } \\
\text { since this alternative was } \\
\text { evaluated and not selectec } \\
\text { as the preferred } \\
\text { alternative. }\end{array}$ & $\begin{array}{l}\text { New facility with } \\
\text { modern controls and } \\
\text { features. }\end{array}$ & $\begin{array}{l}\text { This option is not } \\
\text { deemed a viable } \\
\text { alternative for the } \\
\text { relatively small } \\
\text { volume of } \mathrm{RH} \\
\text { waste to be } \\
\text { processed and the } \\
\text { time and costs } \\
\text { needed to } \\
\text { implement. }\end{array}$ \\
\hline $\begin{array}{l}\text { Com- } \\
\text { mercial } \\
\text { Capability }\end{array}$ & $\begin{array}{l}\text { Acquisition } \\
\text { of Onsite } \\
\text { Commercial } \\
\text { Capability }\end{array}$ & $\begin{array}{l}\text { Remaining } \\
\text { RH-MLLW } \\
\text { and RH-TRU } \\
\text { waste }\end{array}$ & $\begin{array}{l}\text { Low Capital cost } \\
\text { potential. Premium } \\
\text { unit costs per volume } \\
\text { of waste processed is } \\
\text { likely }\end{array}$ & $\begin{array}{l}\text { Interests from } \\
\text { contractors can be } \\
\text { obtained in FY } 07 . \\
\text { Timing for imple- } \\
\text { mentation is highly } \\
\text { uncertain. }\end{array}$ & $\begin{array}{l}\text { A commercial facility } \\
\text { would be required to } \\
\text { protect workers and the } \\
\text { environment from the } \\
\text { hazards associated with } \\
\text { these waste streams. }\end{array}$ & $\begin{array}{l}\text { Regulatory requirements } \\
\text { for such an option are } \\
\text { highly uncertain and } \\
\text { difficult to quantify. A } \\
\text { supplement to the HSW } \\
\text { EIS would be required. }\end{array}$ & $\begin{array}{l}\text { Transfers construc- } \\
\text { tion and startup } \\
\text { costs to the } \\
\text { contractor. }\end{array}$ & $\begin{array}{l}\text { At this time } \\
\text { commercially } \\
\text { available RH-TRU } \\
\text { waste processing } \\
\text { capabilities do not } \\
\text { exist. High unit } \\
\text { costs likely, along } \\
\text { with contractual } \\
\text { penalties if feed } \\
\text { volume is not } \\
\text { maintained. }\end{array}$ \\
\hline
\end{tabular}

(c) RH processing capabilities will be needed for the RH-TRU waste and will be largely dictated by the RH WAC for WIPP. RH processing capabilities will also be needed for the MLLW that can't be treated offsite or in-trench. 


\section{Appendix D-Assumptions}

Table D.1. Proposed Waste Volume Processing Scheme ${ }^{(a)}$

\begin{tabular}{|l|c|c|c|c|c|}
\hline Waste & Process & Type & \% of Total & Volume $\mathbf{( m}^{\mathbf{3}}$ ) & Years \\
\hline \multirow{3}{*}{ MLLW } & \multirow{2}{*}{ In-Trench } & $\mathrm{CH}$ & $40 \%$ & 1,170 & $2007-2010$ \\
\cline { 3 - 6 } & & $\mathrm{RH}$ & $40 \%$ & 74.5 & $2007-2020$ \\
\cline { 3 - 6 } & \multirow{2}{*}{ Offsite } & $\mathrm{CH}$ & $10 \%$ & 292 & $2006-2010$ \\
\cline { 3 - 6 } & \multirow{2}{*}{ RepackageCH } & $\mathrm{CH}$ & $50 \%$ & 18.6 & $2006-2020$ \\
\cline { 3 - 6 } & & $\mathrm{RH}$ & - & - & $2005-2011$ \\
\cline { 3 - 6 } & \multirow{2}{*}{ RH Facility } & $\mathrm{CH}$ & - & - & - \\
\cline { 3 - 6 } & & $\mathrm{RH}$ & $50 \%$ & 93 & $2012-2020$ \\
\hline \multirow{7}{*}{ TRU } & RepackageCH & $\mathrm{CH}$ & $100 \%$ & 4,409 & $2005-2011$ \\
\cline { 3 - 6 } & RH Facility & $\mathrm{RH}$ & $100 \%$ & 365 & $2012-2020$ \\
\hline
\end{tabular}

\section{Waste Volume Estimate Assumptions}

- Mixed Waste smaller than $10 \mathrm{~m}^{3}$ ( $6 \mathrm{ft}$ x $6 \mathrm{ft}$ x $10 \mathrm{ft}$ box) can be routinely processed and treated for disposal using existing onsite capabilities and offsite contracts.

- TRU waste smaller than a Standard Waste Box (SWB) can be processed using existing capabilities (WRAP, APLs or other mobile processing lines and box counters).

- The small volume of CH-TRU waste ( 40.8 $\mathrm{m}^{3}$ forecasted in FY22 and FY25) and RH-TRU waste ( $\sim 4 \mathrm{~m}^{3}, 3.2 \mathrm{~m}^{3}$ / year in FY19-FY28 dropping to $1.9 \mathrm{~m}^{3}$ / year in FY 29-FY34) forecast by the Tank Waste Program after FY 19 are assumed to be either generated earlier (allowing processing through the M-91 capabilities as part of accelerated tank waste processing and closure options) or can be incorporated into the overall Waste Treatment Plant D \&D plans and tank closure processes, if these waste streams are proven to be valid.

\section{Waste Volume Processing Assumptions}

- $10 \%$ of the M-91 MLLW predicted ( $290 \mathrm{~m}^{3}$ oversized CH-MLLW and $\sim 19 \mathrm{~m}^{3}$ of RH-MLLW) can be processed using expanded off-site contracting capabilities (plans are to increase dose rates up to $500 \mathrm{mrem} / \mathrm{hr}$ on contact and routinely process $10 \mathrm{~m}^{3}$ packages with the capabilities to handle special packages up to $14 \mathrm{~m}^{3}$ ). The $\mathrm{CH}$-MLLW volume is assumed to be uniformly processed over a five year period beginning in FY 06. The RH-MLLW volume is assumed to be uniformly processed over a fifteen year period beginning in FY 06 .

- To expand the use of the existing MLLW treatment contracts, it is assumed contracting modifications need to be negotiated and finalized in FY05.

(a) Waste volumes are based on data provided in Appendix B. 
- $40 \%$ of the M-91 MLLW predicted ( 1170 $\mathrm{m}^{3}$ oversized CH-MLLW and $75 \mathrm{~m}^{3}$ of RH-MLLW) can be processed using in-trench treatment capabilities. The CH-MLLW volume is assumed to be uniformly processed over a 4-year period beginning in FY07. The RH-MLLW volume is assumed to be uniformly processed over a 14-year period beginning in FY07.

- To allow in-trench treatment for MLLW permit modifications will need to be negotiated and finalized in FY05/ FY 06.

- $50 \%$ of the oversized CH-MLLW $\left(\sim 1,462 \mathrm{~m}^{3}\right)$ and $100 \%$ of the oversized $\mathrm{CH}$-TRU waste $\left(4,409 \mathrm{~m}^{3}\right)$ must be processed/ treated in a size reduction/ repackaging capability used for the accelerated processing of the M-91 oversized $\mathrm{CH}$ wastes. This combined volume is assumed to be processed at a maximum rate of $1300 \mathrm{~m}^{3} /$ year (assumes the processing of four $5 \mathrm{ft}$ x $5 \mathrm{ft}$ x $9 \mathrm{ft}$ waste boxes per week). Processing is assumed to slowly ramp up using existing capabilities (both 2706-T and T Plant Canyon) beginning in FY05. The maximum processing rate will not be reached until FY07 after facility upgrades and modules have been put in place, allowing processing to be completely current by FY11 (with less than 1\% of the oversized CH-TRU wastes left to be processed as generated).

- To have fully functional CH-oversized waste size reduction/ repackaging capability an engineering study to refine the cost estimates and select the best technical approach must be performed in FY05, allowing need upgrades and/ or the procurement of processing modules to be accomplished in FY06.

- $50 \%$ of the RH-MLLW ( $\left.\sim 93 \mathrm{~m}^{3}\right)$ and $100 \%$ of the RH-TRU waste $\left(365 \mathrm{~m}^{3}\right)$ must be processed/ treated in a $\mathrm{RH}$ processing capability. This combined volume is assumed to be processed at a maximum rate of $50 \mathrm{~m}^{3} /$ year. Processing is assumed to begin in FY12 after facility upgrades and modules have been put in place, allowing processing to be completely current by FY20 (with less than $9 \%$ of the RH-TRU wastes left to be processed as generated).

- To have fully functional RH Processing capability an engineering study to refine the cost estimates and select the best technical approach must be performed in FY07, allowing need upgrades and/ or the procurement of processing modules to be accomplished in FY08 - FY11.

\section{Cost Estimating Assumptions}

- It is assumed that $90 \%$ of the oversized CH-MLLW predicted will be debris and can be treated using macroencapsulation techniques and that the remaining fraction will require thermal or other more extensive treatment after repackaging.

- It is assumed that T Plant will be used (both the 2706-T facility for MLLW and the T Plant Canyon for TRU waste) for the size reduction/ repackaging capability used for the accelerated processing of the M-91 oversized CH wastes.

- It is assumed that T Plant Canyon will be used for the processing/ treatment of the M-91 RH wastes, which can't be processed offsite or in-trench.

- Cost to treat MLLW offsite is assumed to be $\$ 7 \mathrm{~K} / \mathrm{m}^{3}$ for macroencapsulation of oversized CH-MLLW, $\$ 10 \mathrm{~K} / \mathrm{m}^{3}$ for macroencapsulation of RH-MLLW and $\$ 60 \mathrm{~K} / \mathrm{m}^{3}$ for thermal treatment. 
- Cost to treat MLLW in-trench is assumed to be $\$ 4 \mathrm{~K} / \mathrm{m}^{3}$ for oversized $\mathrm{CH}-\mathrm{MLLW}$ and $\$ 7 \mathrm{~K} / \mathrm{m}^{3}$ for RH-MLLW.

- Cost to process/ treat $\mathrm{CH}$ waste in the size reduction/ repackaging facility is assumed to be $\$ 6 \mathrm{~K} / \mathrm{m}^{3}$ for size reduction and macroencapsulation of oversized CH-MLLW (assumed onsite costs savings of 15\% over offsite costs from transportation and other savings), $\$ 8 \mathrm{~K} / \mathrm{m}^{3}$ for repackaging and processing of oversized $\mathrm{CH}-\mathrm{TRU}$ waste, and $\$ 60 \mathrm{~K} / \mathrm{m}^{3}$ for repackaging and processing of MLLW requiring thermal treatment.

- Cost to treat and process the RH-MLLW and RH-TRU waste at an RH facility is assumed to be $\$ 80 \mathrm{~K} / \mathrm{m}^{3}$.

- Costs for facility-wide T Plant upgrades were unchanged.

- T Plant minimum safe operating costs were reduced, beginning in FY10 to account for staffing efficiencies gained better through utilization of T plant staff for both minimum safe operation activities and M-91 processing activities.

- Existing MLLW budgets are sufficient to cover near-term staff activities necessary to obtain regulatory approvals for in-trench treatment and to expand existing MLLW contracts.

- The current budget profiles for M-91 facility development in FY05-FY07 were preserved and are assumed to be sufficient to cover:

- the FY 05 engineering study needed to define the $\mathrm{CH}$ repackaging, size reduction, and treatment capability(s),

- the FY06 T Plant facility upgrades/ modifications needed to specifically support the $\mathrm{CH}$ waste processing mission (e.g., installation of tents or modules in 2706- $\mathrm{T}$ and in the T Plant Canyon),

- the FY07 engineering study for RH processing capabilities, and

- the FY07 procurement activities needed to explore the potential for commercialization of the $\mathrm{RH}$ processing mission.

- The current M-91 budget for construction of the overall M-91 facility was reduced by $15 \%$ (from $\sim \$ 80 \mathrm{M}$ to $\sim \$ 67 \mathrm{M}$ in the FY 08 to FY12 planning window) to account for the reduced scope of the $\mathrm{RH}-$ only processing capability/ modules needed at T Plant. 
Appendix E-Accelerated M-91 Cost Evaluation

Summary Costs (\$M)

Table E.1. Cost Savings Summary

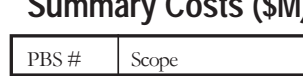

\begin{tabular}{|c|c|c|c|c|c|c|c|c|c|c|c|}
\hline \multicolumn{12}{|c|}{\begin{tabular}{l|l|l} 
CACN & TL 04006 & TL 07.-3
\end{tabular}} \\
\hline$\frac{S \#}{-001}$ & T-P. Pnt Lipord & 4241 & Th & 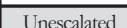 & 0.0 & & 169 & 202 & \multicolumn{3}{|c|}{ 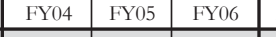 } \\
\hline \multirow[b]{2}{*}{ RL-0013 } & & & & & & & & & & & 12.0 \\
\hline & M-91 Facility - Constru & $4.2 .4 .3 \mathrm{Z}$ & Toall & \begin{tabular}{|l|} 
Unescaluted \\
\end{tabular} & 0.0 & 2.0 & 69.3 & 71.3 & 0.0 & & 1.2 \\
\hline \multirow{4}{*}{\begin{tabular}{l|l} 
RL- -013 \\
RL-0013
\end{tabular}} & 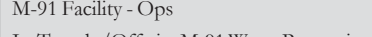 & & & & & 4.4. & & & & & \\
\hline & 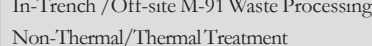 & 4.2 .10 & Toual & 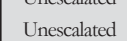 & 0.0 & 0.0 & $\begin{array}{l}8.3 \\
0.0\end{array}$ & 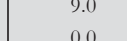 & 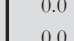 & . & 0.7 \\
\hline & Total & & & & & 45.9 & 324.0 & 369.9 & 12.8 & 16. & 7.0 \\
\hline & Ann & & & & & & & & $\begin{array}{l}0.0 \\
0.0\end{array}$ & (1.) & \\
\hline
\end{tabular}

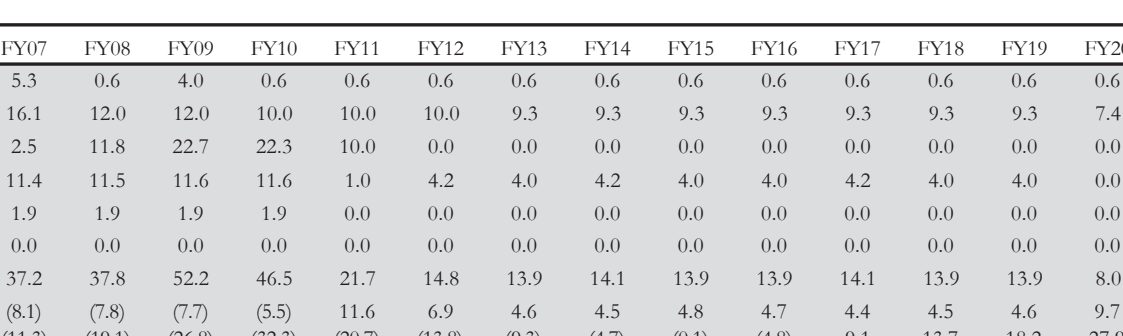

Table E.2. Proposed M-91 Accelerated Processing Approach

\section{Detailed Costs $(\$ K)$}

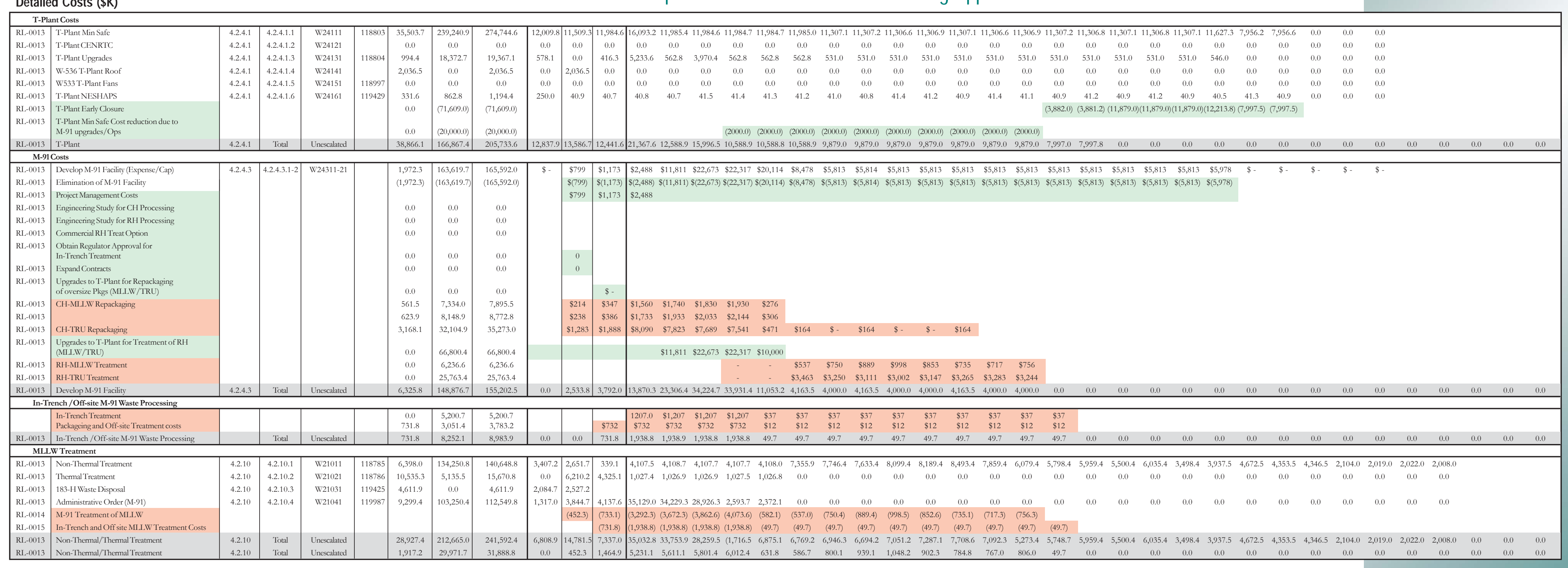

\begin{tabular}{ll|l} 
Rh-0015 & Non-Themal/Themal Treament \\
\hline
\end{tabular} 


\section{Annual Waste Processing Rates $\left(\mathrm{m}^{3}\right)$}

Table E.3. Processing Rate Assumptions

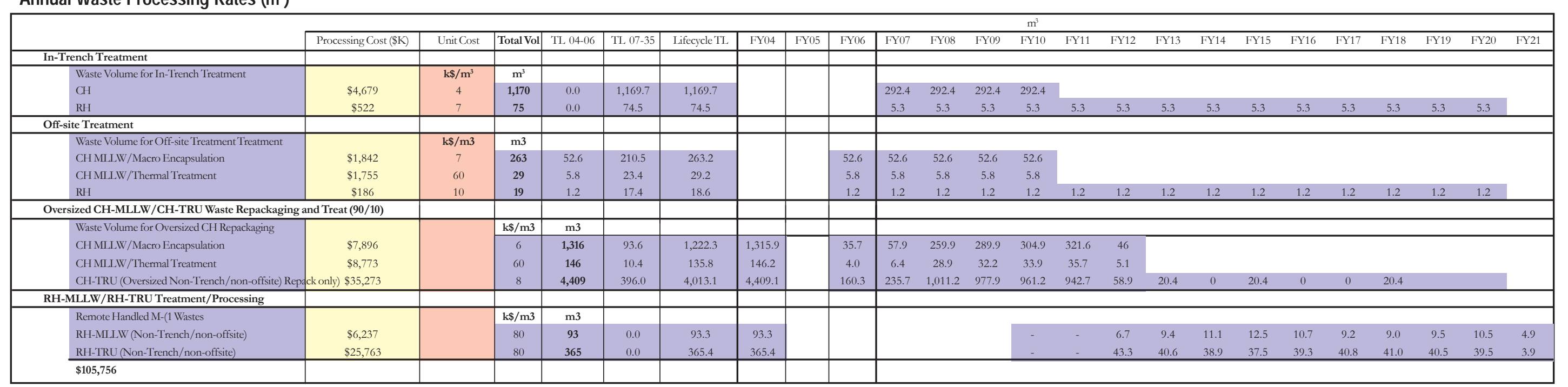

Table E.4. Adjusted December 2003 Baseline Costs

\begin{tabular}{|c|c|c|c|c|c|c|c|c|c|c|c|}
\hline \multicolumn{9}{|c|}{ Summary Costs (\$M) } & \multicolumn{3}{|c|}{ Contract } \\
\hline \begin{tabular}{|l|l|} 
PBS \# & \\
\end{tabular} & Scope & CiAcet & RLLWNBS & CAPN & CACN & TL 0406 & TL 07-35 & Lifiecyld TT & $\begin{array}{ll}\text { FY04 } \\
\end{array}$ & FY05 & FY06 \\
\hline \begin{tabular}{|l|l|l|l} 
RL.0013 \\
\end{tabular} & 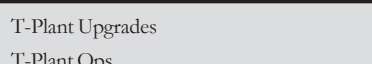 & $4 \cdot 2.2 .1$ & Toal & Unescalhered & & 3.4 .4 & 19.2 & $\begin{array}{l}22.6 \\
2777 \\
279\end{array}$ & 0.8 & 2.1 & $\begin{array}{l}0.5 \\
120\end{array}$ \\
\hline \begin{tabular}{|l|l|} 
RLL-0013 & \\
\end{tabular} & $\begin{array}{l}\text { T-Plant Pos } \\
\text { M-91 Facility-Constrn }\end{array}$ & 4.2 .4 .3 & Toanl & Unsecalated & & 2.6 & $\begin{array}{l}239.2 \\
79.4\end{array}$ & 81.4 & $\begin{array}{l}12.0 \\
0.0\end{array}$ & $\begin{array}{l}11.5 \\
0.8\end{array}$ & $\begin{array}{l}12.0 \\
1.2\end{array}$ \\
\hline & M-91 Faclity - Ops & & & & & 0.0 & & & 0.0 & 0.0 & \\
\hline RL-0013 & Offecting MLLLW Planned Trea & 4.210 & Tonal & 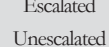 & & 0.0 & 30.0 & 300 & 00 & 00 & 0.0 \\
\hline & . & & & & & 40.8 & 452.1 & 492.9 & 12.8 & 14.4 & 13.6 \\
\hline
\end{tabular}

\section{Detailed Costs (\$K)}

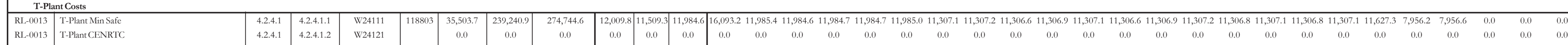

RL-0013 T-Phant Upgates

RL-0013 W533T-Plant Fans

RL-0013 T.PhantNESHAS

\begin{tabular}{ll|l|l|l} 
RL-0013 & T-Plant \\
RL-0013 & T-Plant \\
\hline M
\end{tabular}

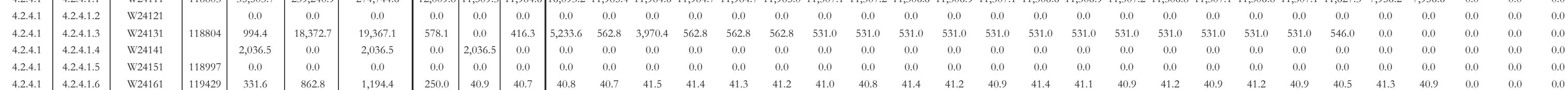

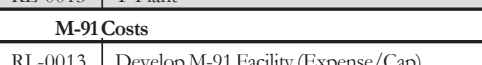

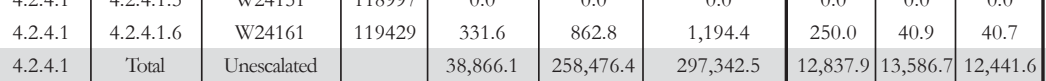

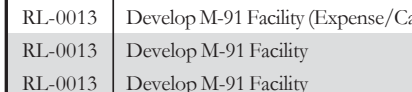

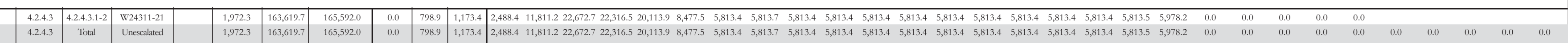

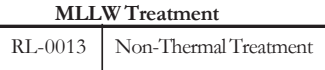

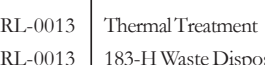

RL-0013 Administrative Order (M-91)

RL-0013 M-91 MLLLW. Treatment Costs

ML-0013 M-91 MLLLW Treatment Costs

$\begin{array}{lll}\text { RLL-0013 } & \text { Non-Therma//hememal Treatrent } \\ \text { Non-Thermal/Themal Treament }\end{array}$

\begin{tabular}{l|l} 
RL-0013 & M-91 MLLWW Treatment Costs \\
\hline
\end{tabular}

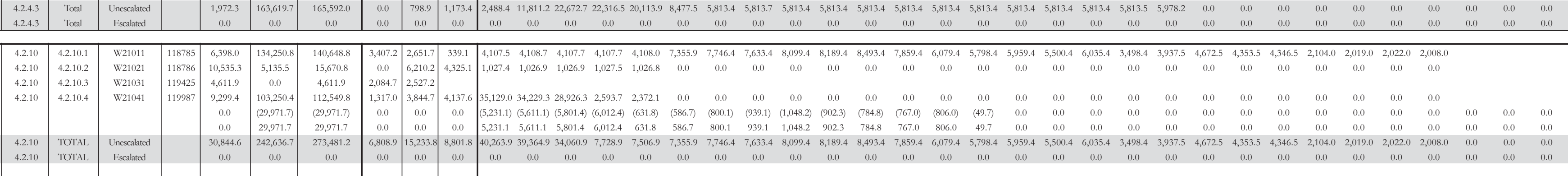

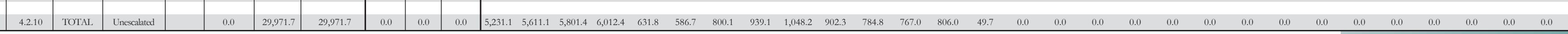




\section{Distribution List}

Fluor Hanford, Inc.

Roberta Barcot

Rick Dunn

Lori Fritz (10)

Jeff Jens

Dave Levinskas

Kent McD onald

Dale McKenney

D ean Nester

Ken Quigley

Virginia Rohay

Dick Wilde

Robert Wilkinson
H8-44

T4-10

H8-44

T4-04

T3-28

T4-10

H8-44

T4-05

H8-44

E 6-35

H8-44

T3-28
PNNL

Tom DeForest (2) K7-97

Linda Fassbender K7-97

Mark Hevland K7-97

Wayne Johnson (5) K K-97

Brian Parker K7-97

Dave Payson K7-90

Paul Scott K9-46

D iana Shankle K9-18

Mike Shay K6-04

Kelli Templeton K7-94

Terry Walton K9-46 
